\title{
De viajes de estampas de arquitectura en el siglo XVIII. El Studio d'Architettura Civile de Domenico de Rossi y su influencia en España*
}

\author{
Delfín Rodríguez Ruiz \\ Universidad Complutense de Madrid
}

\begin{abstract}
RESUMEN: El ensayo que sigue pretende estudiar las diferentes formas de uso y recepción en la España del siglo XVIII de un extraordinario e influyente repertorio de estampas de arquitectura, fundamentalmente de la Roma Barroca y del Renacimiento, como fue el publicado, en tres volúmenes, por Domenico de Rossi, titulado Studio d'Architettura Civile (Roma, 1702, 1711 y 1721). Instrumento de propaganda de la grandeza romana, fue un verdadero manual para la enseñanza de la arquitectura en la Accademia di San Luca durante la primera mitad del Setecientos. Con representaciones en proyección ortogonal de los más importantes edificios de Roma Moderna, incluidos detalles y fragmentos de arquitectura, su difusión en España fue muy temprana, tanto en ámbitos cortesanos como académicos, además de serlo entre otros arquitectos locales, incluidos intelectuales, eruditos, reyes, príncipes y nobles. Esas diferentes maneras de usarlo, en peculiar viaje arquitectónico de modelos romanos, son el objetivo del estudio.
\end{abstract}

PALABRAS CLAVE: Domenico de Rossi, Alessandro Specchi, Ventura Rodríguez, Academia de San Fernando, José de Hermosilla, Representación de la arquitectura, Tratados.

\section{On Architectural Prints Trips in the Eighteenth Century. The Studio d'Architettura Civile by Domenico de Rossi and its Influence in Spain}

\begin{abstract}
The following essay aims to study the different uses and reception in the Eighteenthcentury Spain and influential an extraordinary repertoire of architectural prints, primarily from the Baroque and Renaissance Rome, published in three volumes, by Domenico Rossi, entitled Studio d'Architettura Civile (Rome, 1702, 1711 and 1721). Propaganda instrument of Roman greatness, this work was a real manual for the teaching of architecture at the Accademia di San Luca in the first half of the eighteenth century. Representation on orthogonal projection of the most important buildings of Modern Rome, including details and fragments of architecture, its diffusion in Spain was early, both courtiers and academic areas, in addition to being among other local architects, including intellectuals, scholars, kings, princes and nobles. These different ways of using it, in peculiar traveling Roman architectural models, are the focus of the study.
\end{abstract}

KEY WORDS: Domenico de Rossi, Alessandro Specchi, Ventura Rodríguez, Academia de San Fernando, José de Hermosilla, Architectural Representation, Teatrises.

Recibido: 31 de marzo de 2013 / Aceptado: 2 de mayo de 2013.

* RODRígueZ RUIZ, Delfín: "De viajes de estampas de arquitectura en el siglo XVIII. El Studio d'Architettura Civile de Domenico de Rossi y su influencia en España", Boletín de Arte, n. ${ }^{\circ} 34$, Departamento de Historia del Arte, Universidad de Málaga, 2013, pp. 247-296, ISSN: 0211-8483.

Este ensayo es una versión, nueva y ampliada, del publicado como Delfín Rodríguez Ruiz, "Lo Studio d'Architettura Civile di Domenico de Rossi e la sua influenza in Spagna", en Aloisio Antinori (ed.), Studio d'Architettura Civile. Gli atlanti di architettura moderna e la diffusione dei modelli romani nell'Europa del Settecento, Roma, Ed. Quasar, 2013, pp. 115-141. Algunas de las novedades y precisiones añadidas pude exponerlas durante mi intervención en el Convegno Internazionale di Studi Libri, incisioni e immagini di architettura come fonti per il progetto in Italia (XV-XX secolo), celebrado en la Biblioteca Palatina de Parma durante el 17 y 18 de septiembre de 2012. 
Describía Francisco Preciado de la Vega (1712-1789), en su Arcadia Pictórica en Sueño (1789), un maravilloso palacio dedicado a las Bellas Artes, deteniéndose casi al final de su recorrido en las habitaciones dedicadas a las estampas, lo que le sirvió de excusa para hacer un elogio del grabado y de la representación de obras de arte y de arquitectura en las mismas, ya fueran destinadas a un uso disciplinar entre artistas y arquitectos o para el deleite de eruditos, príncipes y otros aficionados, incluidos posibles coleccionistas de recuerdos. Pintor de origen sevillano, vivió en Roma, en la que escribió su Arcadia, desde 1732 hasta su muerte, llegando a ser secretario y príncipe de la Accademia di San Luca y miembro de la Accademia dell'Arcadia, así como de otras instituciones académicas, con una muy estrecha relación con la de Bellas Artes de San Fernando de Madrid, por la que fue nombrado, a partir de 1758, director de sus pensionados.

Preciado de la Vega elogiaba en su Arcadia, mientras paseaba en sueños por el palacio mencionado, las estampas y el arte del grabado. Comentaba, entre otras cosas, su utilidad para diferentes profesiones y aficionados, incluidos los viajeros, reales o imaginarios, a lo que les eran imprescindibles "las vistas particulares de Palacios, de Ciudades y de sitios considerables, para prevenir las cosas que han de ver ó para conservar las ideas después de haberlas visto". Es decir, para conocer antes de viajar o para recordar después del viaje, pero también para viajar sin moverse del sitio. De hecho, afirma, refiriéndose a las estampas, que "la gran variedad y el gran número de cosas raras, que hallamos en ellas, pueden al mismo tiempo suplir por viages cómodos y curiosos, à los que jamás los han hecho". Aspectos todos que también eran útiles para los arquitectos, sobre todo por "los libros que conciernen á su profesión, y que están llenos de figuras demostrativas de la invención de sus Autores, ó copiadas por el antigüo" ${ }^{1}$. Y es que, según Preciado, entre los "buenos efectos" de las estampas y sus usos estarían los de "representarnos las cosas ausentes, como si las tuviéramos delante de los ojos", así como el de "facilitar la comparación de muchas cosas juntas, mediante el poco sitio que las estampas ocupan" o el de "formar el gusto á las buenas cosas".

Son características, las enunciadas por Preciado de la Vega, que parecen coincidir con especial adecuación -aunque podrían ampliarse a otras coleccio-

1 Francisco Preciado de la Vega, Arcadia Pictórica en Sueño, alegoría ó poema prosaico sobre la teórica y práctica de la pintura, escrita por Parrasio Tebano, Pastor Arcade de Roma..., Madrid, Antonio de Sancha, 1789, pp. 312-313. Sobre Preciado de la Vega véanse, ahora, Jesús Urrea, Relaciones Artísticas Hispano-Romanas en el siglo XVIII, Madrid, Fundación de Apoyo a la Historia del Arte Hispánico, 2006, pp. 141-163 y Alfonso Rodríguez de Ceballos (ed.), Francisco Preciado de la Vega: un pintor español del siglo XVIII en Roma, Madrid, Real Academia de Bellas Artes de San Fernando, 2009, con la bibliografía anterior. 
nes de grabados y tratados- en el fascinante y riquísimo repertorio de estampas de arquitectura, fundamentalmente romana, reunido por Domenico de Rossi (1647-1729) -con la estrecha colaboración, entre otros, del arquitecto, dibujante y grabador Alessandro Specchi (1666-1729)- en sus tres volúmenes del Studio d'Architettura Civile, publicados en la célebre stamperia alla Pace de la familia De Rossi, en 1702, 1711 y 1721, respectivamente, y que el pintor sevillano conocía sin duda alguna. De enorme influencia en la Europa del siglo XVIII y especialmente en España y entre sus arquitectos, ya fueran italianos o españoles que trabajaron al servicio de la Monarquía hispánica en los primeros decenios del Setecientos, muchos de ellos también responsables de la enseñanza académica a partir de mediados del siglo, los volúmenes del Studio de Domenico de Rossi debieron de servir, como decía Preciado, para formar el gusto, ya fuera de príncipes y arquitectos o de aficionados y eruditos, pero también para prever, en su caso, el viaje a Roma y para recordarlo después, incluso también para «suplirlo... à los que jamás lo han hecho".

Se trata, esta última, de una observación que confirmaba, con enfática y extraña convicción, Jovellanos a propósito del grandísimo arquitecto Ventura Rodríguez (1717-1785), del que escribía, en 1788, en el Elogio que le dedicó, que: "Vosotros, los que para rebaxar su mérito habeis repetido con tanta afectación: nunca estuvo en Roma: venid, observadle, acompañadle en este estudio, y decidme después ${ }^{2}$. Y en efecto, Ventura Rodríguez, que nunca estuvo en Roma, fue posiblemente el más romano -usando conscientemente la tradición de Miguel Ángel y Bernini a Carlo Fontana, de Rainaldi a Borromini- de los arquitectos españoles, barroco y académico, como buscaba serlo en la España de mediados del siglo XVIII ${ }^{3}$. Es más, sus citas constantes a esos arquitectos y a sus edificios y lenguajes, ya fueran escritas o construidas, dibujadas o proyectadas, confirman esa adscripción barroca romana del discípulo de Filippo Juvarra (1678-1736) y del mismo Giovanni Battista Sacchetti (1690-1764) durante sus primeros años de actividad en el Palacio Real Nuevo de Madrid [1]. Fue, en definitiva, uno de esos arquitectos, tan frecuentes en España, que suplió el viaje a Roma mediante el uso de las estampas y, entre ellas, las de Rossi, Fontana y tantos otros.

2 Gaspar Melchor de Jovellanos, Elogio de D. Ventura Rodríguez, Madrid, Viuda de Ibarra, 1788, p. 16. La obra de Jovellanos sobre Ventura Rodríguez fue la primera monografía independiente dedicada a un arquitecto en la historia del arte español.

3 Sobre el carácter barroco de la arquitectura de Ventura Rodríguez, especialmente entre finales de los años cuarenta y hasta mediados de los años setenta del siglo XVIII, sigue siendo imprescindible el clásico ensayo de Fernando Chueca Goitia, "Ventura Rodríguez y la escuela barroca romana", Archivo Español de Arte, n. ${ }^{\circ}$ 52, 1942, pp. 185-210. 


\section{D: artículos}

Delfín Rodríguez Ruiz

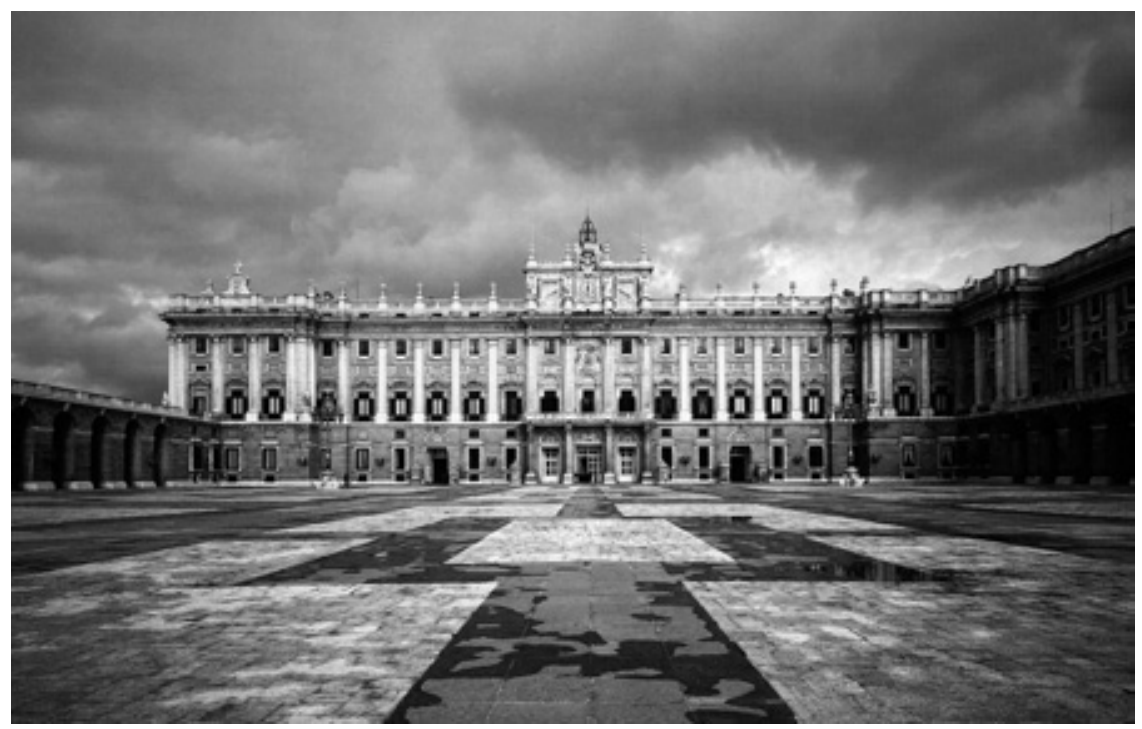

1. Madrid. Palacio Real. 1738-1764. Giovanni Battista Sacchetti

Por otra parte, se trata de referencias y citas, las que pueden encontrarse sin dificultad en las obras de Ventura Rodríguez ${ }^{4}$, que fueron posibles gracias al manejo habitual de tratados y repertorios como los de Giovanni Giacomo y Domenico de Rossi, muchos de los cuales poseyó en su espléndida biblioteca ${ }^{5}$, aunque también debió conocerlos y usarlos procedentes de las bibliotecas de sus maestros italianos (Juvarra o Sacchetti, sin olvidar su trato en las obras reales con otros artistas), así como en la magnífica biblioteca de su íntimo amigo el escultor Felipe de Castro (1711-1775), quien junto a Preciado de la Vega residió también en Roma, entre 1733 y 1747, y que, con Ventura Rodríguez, trabajó como escultor en la decoración del Palacio Real de Madrid [2 a y b], compartiendo, además, la enseñanza e importantes cargos institucionales en la Real Academia de Bellas Artes de San Fernando, ya desde sus orígenes en 1744, pero sobre todo a partir de su fundación oficial en 1752.

4 Sobre esas referencias y citas tipológicas y ornamentales en sus dibujos de arquitectura he tratado recientemente en Delfín Rodríguez Ruiz, «Dibujos de Ventura Rodríguez», en Isabel García Toraño (ed.), Dibujos de Arquitectura y Ornamentación de la Biblioteca Nacional. Tomo II. Siglo XVIII, Madrid, Biblioteca Nacional, 2009, pp. 120-150, con la bibliografía anterior.

5 José Luis Blanco Mozo, "La cultura de Ventura Rodríguez. La biblioteca de su sobrino Manuel Martín Rodríguez", Anuario del Departamento de Historia y Teoría del Arte, Universidad Autónoma de Madrid, vols. VII-VIII, 1995-1996, pp. 181-220. 
A

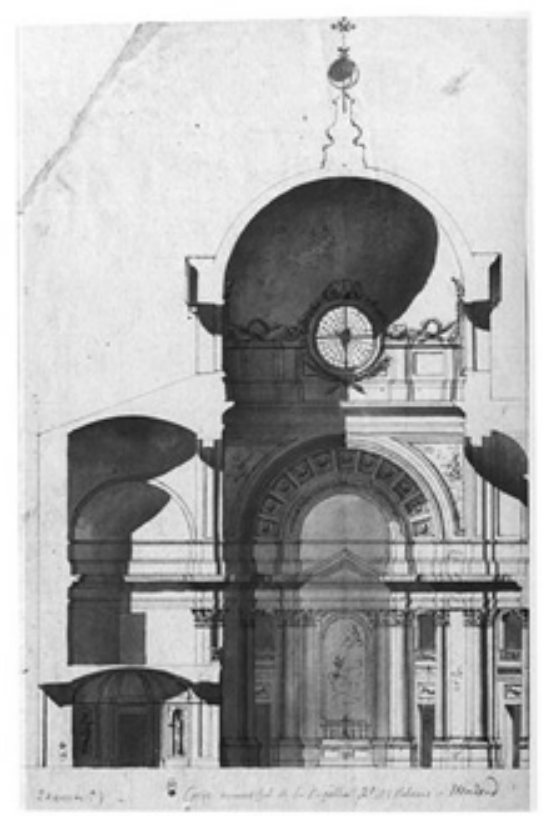

B

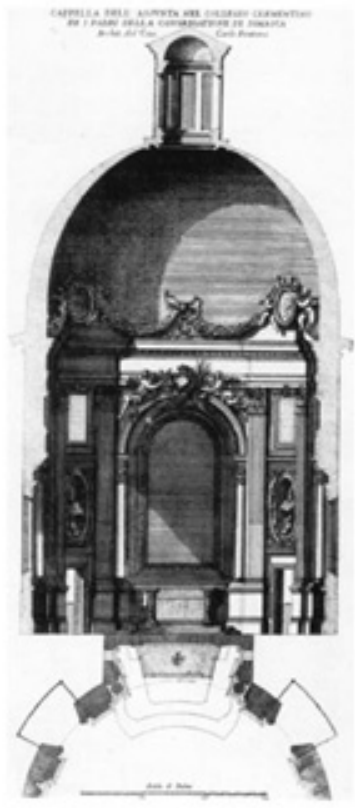

2. A) Giovanni Battista Sacchetti, Proyecto para la capilla del Palacio Real de Madrid. Sección. Dibujo a pluma, tinta y aguada gris, ca. 1753-1754 (Madrid, Biblioteca Nacional). B) Gio. Giacomo de Rossi, Disegni di Vari Altari e Cappelle (1688-1690), Lám. 40: Cappella dell Assunta nell'Collegio Clementino di Roma, de Carlo Fontana

Estas observaciones previas no solo pretenden confirmar e ilustrar las afirmaciones de Preciado de la Vega sobre la utilidad y formas de circulación y usos de las estampas entre arquitectos y artistas, dejando profundas huellas en su formación y en sus proyectos, sino que, además, establecen históricamente la cartografía imaginaria que vincula los modelos romanos -en este caso los difundidos en las láminas del Studio d'Architettura Civile de D. de Rossi- y su recepción en España, trazada por medio de caminos que no solo fueron institucionales o académicos, a veces simplemente librescos, sino que se atan estrechamente a los itinerarios recorridos por arquitectos y artistas viajeros, con frecuencia de origen italiano, y a sus relaciones. Es más, de un modo elocuente y práctico, Preciado de la Vega señalaba cómo las estampas podían servir también para la invención de obras cuyas referencias concretas pudieran estar ausentes en otros lugares -como ocurre con los ejemplos de las arquitecturas romanas representadas en el Studio de Domenico de Rossi-, permaneciendo el arquitecto como si las tuviera delante de los ojos. Es decir, eran útiles sobre todo para invenciones de quien no 
hubiera viajado nunca a Roma ${ }^{6}$, como era el caso de Ventura Rodríguez y de otros muchos, ya que les permitían proyectar mediante representaciones pensadas especialmente para ellos, con un riguroso control de los sistemas de representación arquitectónica en proyección ortogonal, con plantas, alzados y secciones, acompañadas de escalas. $Y$ se trata de una cuestión que ya en el entorno académico de la Accademia di San Luca ${ }^{7}$ y de Carlo Fontana ${ }^{8}$ y sus discípulos (entre ellos, por supuesto, arquitectos como Juvarra o Specchi) era una forma canónica y académica de dibujar y proyectar la arquitectura ${ }^{9}$, lo que habría de tener un papel fundamental en la misma Academia de Bellas Artes de San Fernando y aún antes, especialmente a partir de la presencia de Juvarra en España.

Ese uso de las estampas parece especialmente ejemplificado en el que Ventura Rodríguez hizo -como coleccionista apasionado de representaciones de arquitecturas ausentes y en sus dibujos, proyectos y edificios- de las de Domenico de Rossi y también de las de otros repertorios y tratados que figuraban en su biblioteca o en la de sus amigos, arquitectos o no, de los de Domenico Fontana o Borromini a los de Carlo Fontana o Ferdinando Ruggieri, sin olvidar los de su propio maestro Filippo Juvarra, cuyas obras también poseyó, incluidos dos dibujos, de 1709, con vistas del Capitolio romano, que llegó a ver Jovellanos ${ }^{10}$

6 Delfín Rodríguez Ruiz, "ll grand tour dei linguaggi architettonici: Roma-Napoli-Madrid», en Alfonso Gambardella (ed.), Napoli-Spagna. Architettura e città nel XVIII secolo, Nápoles, Edizioni Scientifiche Italiane, 2003, pp. 21-24.

7 Paolo Marconi, Angela Cipriani y Enrico Valeriani (eds.), I disegni di architettura dell'Archivio storico dell'Accademia di San Luca, 2 vols., Roma, De Luca Ed., 1974 y Hellmut Hager (ed.), Architectural Fantasy and Reality. Drawings fron the Accademia di San Luca in Rome. Concorsi Clementini 1700-1750, Pennsylvania, Museum of Art The Pennsylvania State University, 1981.

8 Allan Braham y Hellmut Hager, Carlo Fontana. The Drawings at Windsor Castle, Londres, A. Zwemmer Ltd., 1977.

9 Véanse, entre otros, los estudios de Elisabeth Kieven, "ll ruolo del disegno", en Bruno Contardi y Giovanna Curcio (eds.), In Urbe Architectus. Modelli, Disegni, Misure. La profesione dell'architetto Roma 1680-1750, Roma, Àrgos, 1991, pp. 124-142; Giovanna Curcio y Elisabeth Kieven (eds.), Storia dell'architettura italiana. II Settecento, 2 vols., Milán, Electa, 2000 y Giuseppe Dardanello, "Pensieri e disegni -ragione e seduzione- Guarini e Juvarra», en Giuseppe Dardanello y Rosa Tamborrino (eds.), Guarini, Juvarra e Antonelli. Segni e simboli per Torino, Milán, Silvana, 2008, pp. 18-35.

10 Jovellanos escribe, en su elogio de Ventura Rodríguez, que su sobrino, el arquitecto Manuel Martín Rodríguez, poseía como herencia de su tío «además de un buen retrato de Juvarra dos dibuxos originales de su mano, que representan dos vistas del Capitolio, hechas de aguadas y en una manera tan libre y graciosa que prueban bien el superior gusto y destreza con que aquel insigne arquitecto manejaba la pluma. Las firmas que se leen en ambos dice así: Veduta del Campidoglio di Roma, come al presente si trova, disegnata da me n'el di 26 de Marzo 1709 Filipp. luvarra arquitecto.» Citado en Gaspar Melchor de Jovellanos, Elogio de D. Ventura Rodríguez..., p. 74. Los dibujos de Juvarra que describe Jovellanos y que habían pertenecido a Ventura Rodríguez, hoy no conservados, debían de ser muy semejantes, si no es que eran copias, de los que se guardan en el Gabinetto Comunale delle Stampe de Roma. Sobre estos últimos pueden verse, entre otros, John Pinto, «Filippo Juvarra's Drawins Depicting the Capitoline Hill", Art Bulletin, n. ${ }^{\circ} 62,1980$, pp. 598-616 y Elisabeth Kieven (ed.), Architettura del Settecento a Roma nei Disegni della Raccolta Grafica Comunale, Roma, Edizioni Carte Segrete, 1991, pp. 29-30. Sobre los dibujos de Juvarra conservados en la Biblioteca Nacional (Madrid), véase Delfín Rodríguez Ruiz, "Dibu- 
y que, en cierta medida, parecen haberse inspirado precisamente en la vista, de 1706, del Porto di Ripetta de Alessandro Specchi ${ }^{11}$, protagonista fundamental de los dibujos grabados en el Studio d'Architettura Civile y autor del proyecto y construcción del mencionado puerto romano y de la estampa citada.

Ciertamente, como afirmaba Preciado de la Vega, las estampas podían servir al arquitecto, al artista o al aficionado para tener presentes edificios y ornatos de otros lugares, en ausencia de los mismos y como posibles modelos ejemplares, útiles para formar el buen gusto o crear nuevas invenciones y proyectos sin necesidad de hacer el viaje o tomar apuntes de lo visto, guardándolos en la memoria dibujada para mejor ocasión. Pero hay otro aspecto de su relato que resulta de especial importancia para entender el modo de uso de esas colecciones de estampas. Me refiero a la observación en la que menciona que las estampas "facilitan la comparación de muchas cosas juntas", a lo que cabría añadir "como si las tuviéramos delante de los ojos". Y no cuesta esfuerzo alguno imaginar a un arquitecto como Ventura Rodríguez (y a otros muchos que nunca estuvieron en Roma) rodeado de decenas de láminas de la Roma barroca, de Bernini, Pietro da Cortona y Borromini a Carlo Fontana o Rainaldi, para componer sus proyectos, poniendo en evidencia su cultura visual y el estudio riguroso de los modelos a partir de esas representaciones arquitectónicas, como si cada imagen grabada pudiera dar razón de sus propias soluciones y fragmentos de arquitectura, trazando, a partir de frases de distinto origen, un discurso propio: es decir, en este caso, una síntesis de la arquitectura romana leída en clave hispánica que acabó convirtiéndose en modelo académico en los años centrales del siglo XVIII.

En ese sentido hizo uso Ventura Rodríguez $-y$, antes que él mismo, algunos otros arquitectos- de obras de la stamperia de Rossi como el Insigniun Romae Templorum (1684), los Disegni di Vari Altari e Cappelle (1689-1691?) de Giovanni Giacomo de Rossi o el fundamental Studio d'Architettura Civile $(1702,1712$ y 1721) de Domenico de Rossi para resolver sus proyectos. De hecho, en muchas ocasiones remitía necesariamente, ya que jamás estuvo en Roma, a las láminas de esas obras para defender sus propias ideas y soluciones, como ocurriera con motivo de su respuesta, en 1751, a las críticas a la que fueron sometidos sus planos para la Santa Capilla de Nuestra Señora del Pilar de Zaragoza [3]. En esa respuesta se refería a iglesias, baldaquinos y altares romanos con tanta soltura que parecía que

jos de Filippo Juvarra", en Isabel García Toraño (ed.), Dibujos de Arquitectura y Ornamentación..., pp. 263-280, con la bibliografía anterior.

11 Sobre el Porto di Ripetta de Alessandro Specchi véanse, entre otros, Thomas Ashby, "Alessandro Specchi", Town Planning Review, Vol. XII, n. ${ }^{\circ} 4,1927$, pp. 237-248 y Tod A. Marder, "The Porto di Ripetta in Rome", Journal of the Society o Architectural Historians, vol. XXXIX, 1980, pp. 28-56. 


\section{Dartículos}

Delfín Rodríguez Ruiz

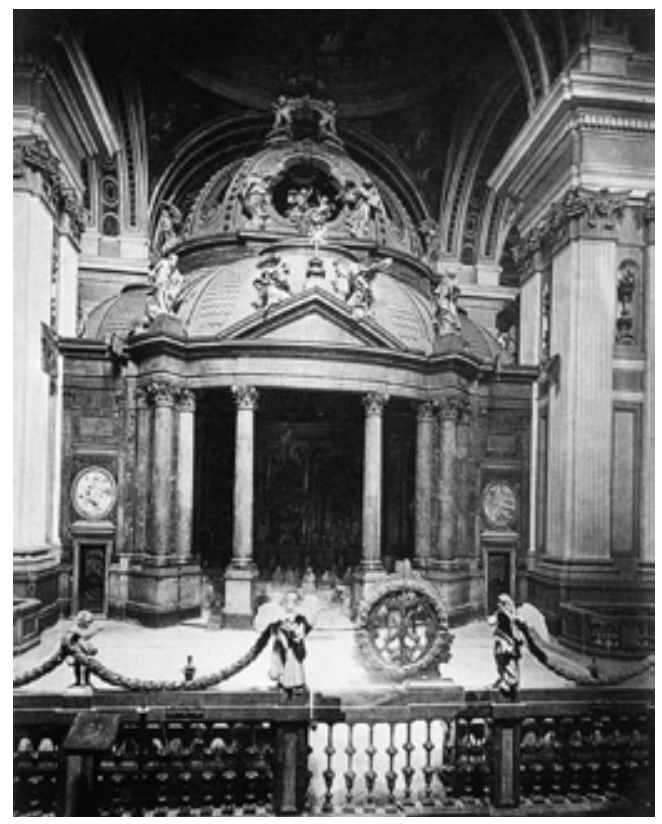

3. Zaragoza. Basílica de

Nuestra Señora del Pilar. Santa Capilla. 1750-1765. Ventura

Rodríguez. Fotografía de Jean

Laurent, 1874-1877

los hubiera conocido directamente, del Baldaquino de San Pietro de Bernini, al del "Cav. ${ }^{\circ}$ Carlos Rainaldi en el que hizo en la misma ciudad en Santa María de la Escala, y el $\mathrm{Cav}^{\circ}$. Carlos Fontana en el de la Transportina, sin referir otros ejemplares que, además de los citados, son vivos ejemplos de los profesores", añadiendo, en su defensa, menciones a Sant'Andrea al Quirinale y Santa Maria Assunta in Ariccia, del Bernini, así como Santa Maria di Monte Santo y Santa Maria dei Miracoli en la Piazza del Popolo, y también una particular referencia a Borromini: "Que muy repetidos y aprobados ejemplares de antiguos y modernos hay en Roma que defiendan estar bien adaptadas las cabezas grandes con alas de Querubines, particularmente en las obras del $\mathrm{Cav}^{\circ}$. Borromini, así en la iglesia de San Juan de Letrán [...] como en la célebre iglesia de San Carlos a las Cuatro Fuentes, en la Sapienza y en otras [...]»"12. Todo lo cual confirma su conocimiento preciso de las obras de Gian Giacomo y de Domenico de Rossi mencionadas, especialmente el Studio d'Architettura Civile, aunque también poseía en su biblioteca la Opera del

12 Fernando Chueca Goitia, "Ventura Rodríguez y la escuela barroca romana...», pp. 186 y ss. Al respecto véanse también Thomas F. Reese, The Architecture of Ventura Rodríguez, 2 vols., Nueva York, Garland, 1976; Antonio Fernández Alba (ed.), El Arquitecto Ventura Rodríguez (1717-1785), Madrid, Museo Municipal, 1983 y Ricardo Usón, La intervención de Ventura Rodríguez en El Pilar. La Santa Capilla generatriz de un sueño arquitectónico, Zaragoza, Colegio Oficial de Arquitectos de Aragón, 1990. 
Caval. Francesco Borromini Cavata dei suoi originali ciò̀ La Chiesa, e Fabrica della Sapienza di Roma (1720).

Se trata de un uso erudito y disciplinarmente arquitectónico de las estampas de la arquitectura romana en el que las obras de los De Rossi o Carlo Fontana cumplieron un papel decisivo, contribuyendo a una síntesis que, en su arquitectura y en la Academia de San Fernando -a pesar de otras influencias francesas y del modelo de El Escorial, que él mismo incorporaría tempranamente-, acabaría siendo canónica ${ }^{13}$, especialmente en los dibujos de presentación realizados por los jóvenes arquitectos para competir en los concursos convocados por la propia institución. Y esa Roma moderna, conocida a través de las estampas pensadas a propósito, por Domenico de Rossi y Alessandro Specchi, para los arquitectos y para su formación, es la que muy pronto conoció Ventura Rodríguez, primero por su relación con maestros italianos como Juvarra o Giovanni Battista Sacchetti e inmediatamente después, a partir de 1747, a través de la riquísima biblioteca de su amigo el escultor Felipe de Castro, recién regresado de su estancia romana. No parece casual, por tanto, que en 1748 presentara, para su nombramiento como académico de mérito en la Accademia di San Luca di Roma, un magnífico proyecto para una catedral ${ }^{14}$ en el que sintetiza toda su cultura arquitectónica romana, conocida mediante las colecciones de estampas mencionadas y especialmente las de Domenico de Rossi.

El interés de su proyecto de catedral [4 a y b] reside, en ese sentido, en que se trata de una composición académica en la que pueden identificarse sin dificultad ejemplos y ecos de modelos romanos muy conocidos, del San Pedro del Vaticano de Miguel Ángel, Maderno y Bernini a evidentes citas de Santa Agnese in Piazza Navona, de Rainaldi y Borromini, así como a la Basílica de Superga de Juvarra, entre otras referencias. Es decir, como si pretendiese, ante la Accademia di San Luca di Roma, mostrar su erudición romana e italiana y la desenvoltura en las citas para componer un proyecto que es casi un repertorio de estampas combinadas, una especie de aplicación casi exacta de la colección contenida, por ejemplo, en los tres volúmenes del Studio de De Rossi. Volúmenes que sirvieron -lo que ha

13 Delfín Rodríguez Ruiz, "Arquitectura y Academia durante el reinado de Fernando Vl», en Antonio Bonet Correa y Beatriz Blasco (eds.), Un reinado bajo el signo de la paz. Fernando VI y Bárbara de Braganza (1746-1759), Madrid, Real Academia de Bellas Artes de San Fernando, 2002, pp. 219-243.

14 Los dibujos del proyecto de Ventura Rodríguez fueron reproducidos en Paolo Marconi, Angela Cipriani y Enrico Valeriani (eds.), I disegni di architettura..., vol. 2, ils. 2169-2171. Al respecto de los mismo véanse George Kubler, Arquitectura de los siglos XVII y XVIII, vol. XIV de Ars Hispaniae, Madrid, Ed. Plus Ultra, 1957, p. 244; Thomas F. Reese, The Architecture of Ventura Rodríguez..., vol. I, pp. 48-53; Carlos Sambricio, "Sobre la formación de Ventura Rodríguez", Academia, n. ${ }^{\circ}$ 53, 1981, pp. 121-147 y Delfín Rodríguez Ruiz, "Arquitectura y Academia...", pp. 221-223. 

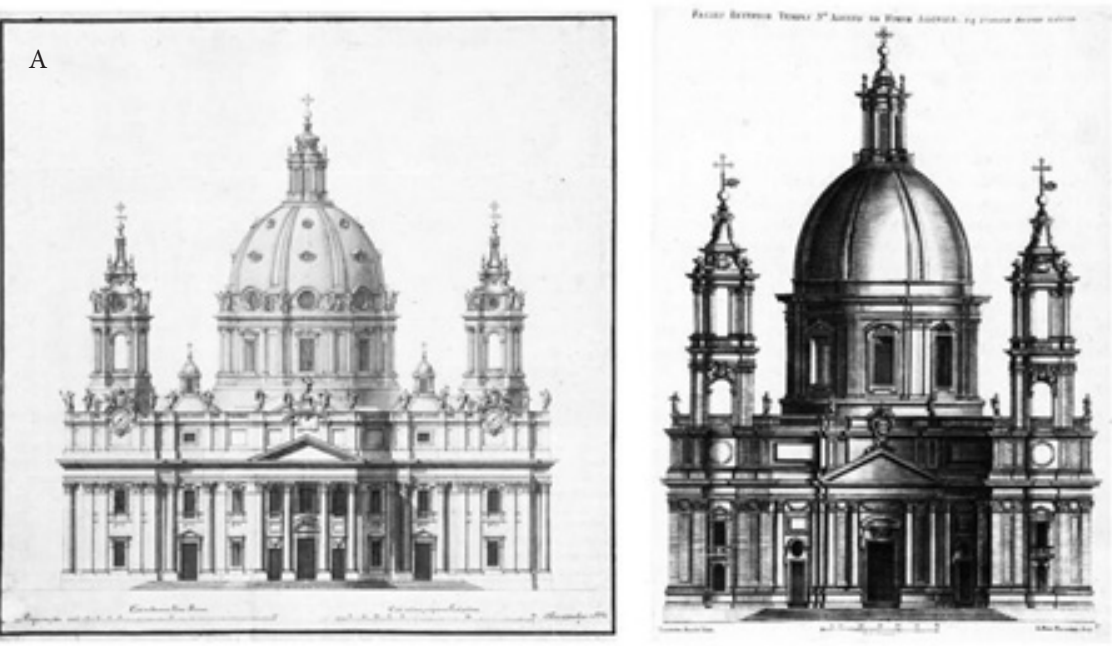

4. A) Ventura Rodríguez, Proyecto para una catedral. Alzado de la fachada. Dibujo a pluma y aguadas, 1748 (Roma, Accademia di San Luca). B) Gio. Giacomo de Rossi, Insignium Romae Templorum Prospectus, 1684, Lám. 17: Facciata della Chiesa di Sant'Agnese in Agone, de Francesco Borromini y Carlo Rainaldi

sido observado en diferentes ocasiones, de Hager a Connors- como una especie de manual intencionadamente pensado para los estudiantes y participantes en los concursos de la academia romana durante la primera mitad del siglo XVIII.

Con ese proyecto y el reconocimiento de la Accademia di San Luca, Ventura Rodríguez sentaba, indirectamente, las bases de los modelos que habrían de servir de referencia en la propia Academia de Bellas Artes de San Fernando a partir de los años siguientes. Y cabe recordar que aún no había construido ninguna obra propia, ya que la primera, comenzada en 1749, sería la Iglesia de San Marcos de Madrid [5 a y b], en la que combina -como ya observara atinadamente Chueca Goitia- a Juvarra (San Filippo di Torino) con Borromini (San Carlo alle Quattro Fontane) y, en la fachada, ecos de la de Sant'Andrea al Quirinale, de Bernini, además de otros ejemplos de altares romanos que, a través de Disegni di Vari Altari e Cappelle, están presentes en los que diseñó para la misma iglesia o para la reforma que realizó en la del Monasterio de la Encarnación, en Madrid, entre 1755 y 1767 [6 a y b].

Se trata de ejemplos, los mencionados de Ventura Rodríguez, que ilustran con precisión el modo de uso, tal como lo describiera Preciado de la Vega, y la importancia, en la arquitectura española del siglo XVIII, de repertorios como el 


\section{Q artículos}

De viajes de estampas...
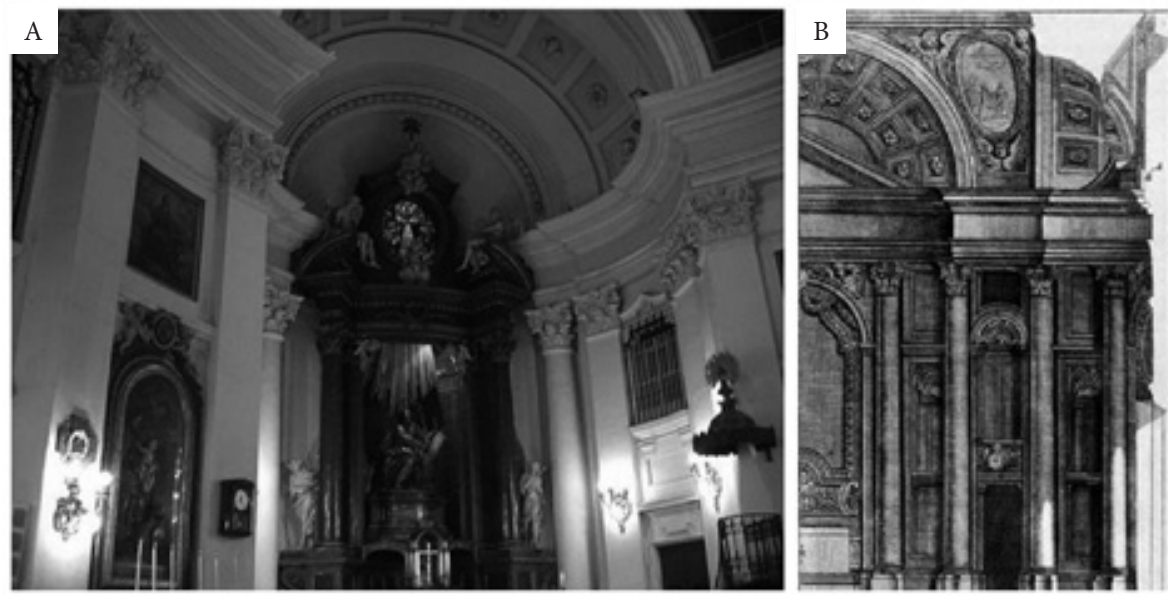

5. A) Madrid, Interior de la iglesia de San Marcos (1749). Ventura Rodríguez. B) Domenico de Rossi, Studio d'Architettura Civile, II (1711), Lám. 18: Spaccato interiore della metà della chiesa di San Carlo alle Quattro Fontane, de Francesco Borromini
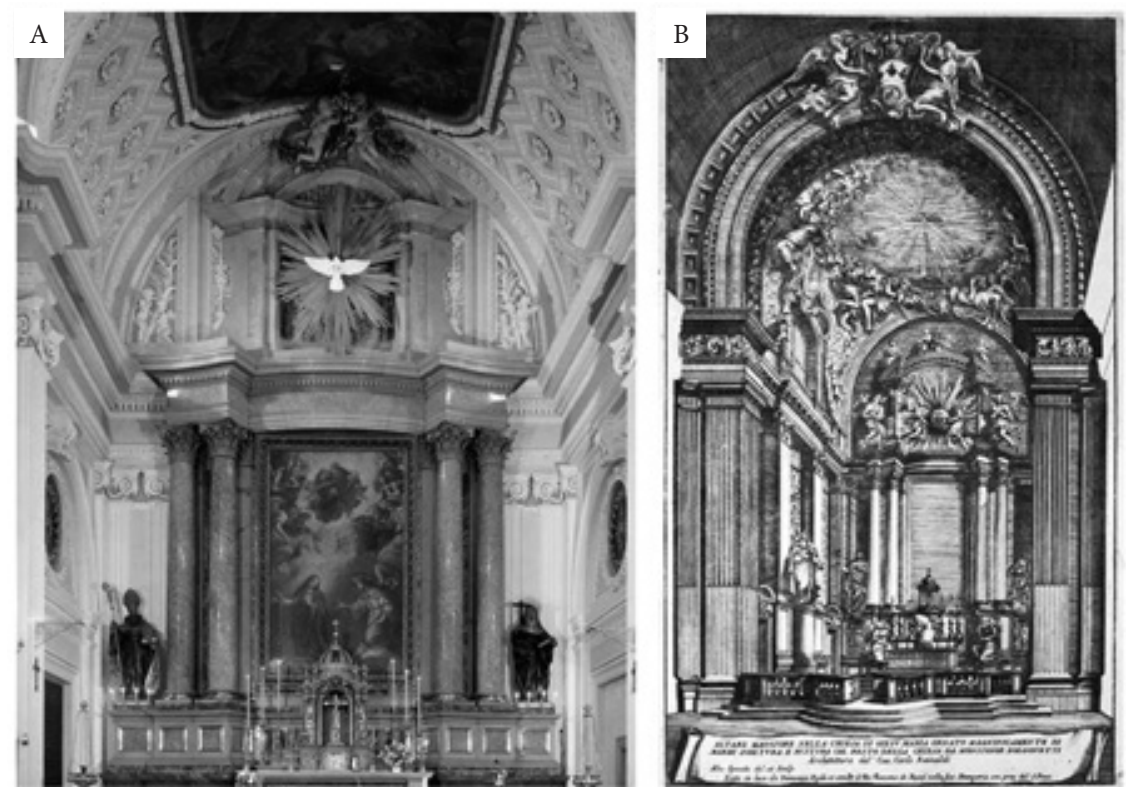

6. A) Madrid, Monasterio de la Encarnación. Altar mayor, 1755-1767. Ventura Rodríguez. B) Gio Giacomo di Rossi e Domenico Rossi, Disegni di Vari Altari e Cappelle, (1690), Lám. 48: Altare Maggiore della Chiesa di Gesù e Maria, de Carlo Fontana 
Studio d'Architettura Civile, entre otras obras también publicadas por la stamperia de Rossi ${ }^{15}$, con una más que evidente influencia, desde las primeras décadas del siglo -casi recién publicados los tres volúmenes mencionados-, en ámbitos cortesanos y académicos ${ }^{16}$.

La publicación del Studio tuvo una temprana repercusión en España en los ambientes artísticos relacionados con la corte y en otros círculos de arquitectos $^{17}$, así como en obras de promoción eclesiástica o regia, vinculado a menudo con algunas otras colecciones de estampas y tratados, de las de Carlo Fontana a

15 Sobre Gian Giacomo y Domenico de Rossi pueden verse, entre otros, Gabriele Morolli, "Un saggio di editoria barocca: i rapporti Ferri-De Rossi-Specchi e la trattatistica architettonica del Seicento romano", en Marcello Fagiolo (ed.), Gian Lorenzo Bernini e le arti visive, Roma, Istituto della Enciclopedia Italiana, 1987, pp. 209-240; Simona Ciofetta, "Lo Studio d'Architettura Civile edito da Domenico de Rossi (1702, 1711, 1721), en Bruno Contardi y Giovanna Curcio (eds.), In Urbe Architectus. Modelli, Disegni, Misure. La professione dell'architetto Roma 1680-1750, Roma, Argos, 1991, pp. 214-219; Francesca Consagra, The De Rossi Family Print Publishing Shop: A Study in the History of the Print Industry in Seventeenth-Century Rome, (Ph. D., The Johns Hopkins University, Baltimore, 1992), Ann Arbor Michigan, 1993; Martha Pollak (ed.), The Mark J. Millard Architectural Collection. Vol. IV. Italian and Spanish Books, Washington, National Gallery of Art, 2000, pp. 345-359; Anna Grelle lusco (ed.), Indice delle Stampe intagliate in rame a bulino, e in acqua forte esitenti nella Stamperia di Lorenzo Filippo de' Rossi. Contributo alla storia di una stamperia romana, Roma, Artemide Edizioni, 1996; Simona Ciofetta, "Alcune edizioni di architettura di Gian Giacomo e Domenico De Rossi: fasi preparatorie e finalità dell'opera", en Studi sul Settecento romano, n. ${ }^{\circ} 13-1997$, pp. 65-73 y Andor Gomme, "Smith and Rossi", Architectural History, vol. 35, 1992, pp. 183-19. En general, sobre Alessandro Specchi, su arquitectura y sus dibujos para el Studio d'Architettura Civile editado por Domenico de Rossi véase, con la bibliografía anterior, Gianfranco Spagnesi, Alessandro Specchi. Alternativa al borrominismo, Turín, Testo \& Immagine, 1997. 16 Sobre la arquitectura y el arte cortesanos y académicos en la España del siglo XVIII pueden verse, entre otros, Yves Bottineau, El arte cortesano en la España de Felipe V (1700-1746), Madrid, Fundación Universitaria Española, 1986; Carlos Sambricio, La arquitectura española de la llustración, Madrid, Consejo Superior de los Colegios de Arquitectos de España, 1986; Claude Bédat, La Real Academia de Bellas Artes de San Fernando, 1744-1808, Madrid, Fundación Universitaria Española, 1989; José Luis Sancho, La arquitectura de los Sitios Reales, Madrid, Patrimonio Nacional, 1995; Jesús Urrea, Relaciones artísticas Hispano-Romanas en el siglo XVIII, Madrid, Fundación de Apoyo a la Historia del Arte Hispánico, 2006; Antonio Bonet Correa, "Utopía y realidad en la Arquitectura", Antonio Bonet Correa (ed.), Domenico Scarlatti en España, Madrid, Ministerio de Cultura, 1985, pp. 19-82; Antonio Bonet Correa (ed.), El Real Sitio de Aranjuez y el arte cortesano del siglo XVIII, Madrid, Comunidad de Madrid, 1987; Antonio Bonet Correa y Beatriz Blasco (eds.), Filippo Juvarra (1678-1736). De Messina al Palacio Real de Madrid, Madrid, Ministerio de Cultura, 1994; Antonio Bonet Correa y Beatriz Blasco (eds.), Un reinado bajo el signo de la paz. Fernando VI y Barbara de Braganza, Madrid, Real Academia de Bellas Artes de San Fernando, 2002; Delfín Rodríguez Ruiz (ed.), El Real Sitio de La Granja de San Ildefonso. Retrato y escena del Rey, Madrid, Patrimonio Nacional, 2000 y Delfín Rodríguez Ruiz (ed.), Palacios Reales en España. Historia y arquitectura de la magnificencia, Madrid, Fundación Argentaria, 1996.

17 La bibliografía sobre bibliotecas españolas del siglo XVIII, con presencia importante en muchas ocasiones de libros y colecciones de estampas relativos a las artes y a la arquitectura, es enorme y su estudio, uso y funciones comienza a ser objeto de diferentes interpretaciones y análisis históricos. Véanse, al respecto, entre otras muchas citadas en este breve ensayo, las aportaciones de Luis Miguel Enciso Recio, Barroco e llustración en las bibliotecas privadas españolas del siglo XVIII, Madrid, Real Academia de la Historia, 2002; Daniel Crespo Delgado, "Lectura y lectores en la España de la llustración. El caso de la literatura artística", Cuadernos de Historia Moderna, n. ${ }^{\circ} 32,2007$, pp. 31-60 y Ramón Soler i Fabregat, "Libros de arte en bibliotecas de artistas españoles (siglos XVI-XVIII): aproximación y bibliografía", Locus Amoenus, n. ${ }^{\circ} 1$, 1995, pp. 145-164. En general, sobre bibliotecas de arquitectos, puede verse Olga Medvedkova (ed.), Bibliothèques d'architecture. Architectural libraries, París, INHA, 2009. 
las de Andrea Pozzo, tan habitualmente presente en la cultura española del siglo XVIII, conservándose incluso una traducción manuscrita al castellano ${ }^{18}$ en las mismas páginas de la edición que, en Roma, hiciera Antonio de Rossi, en 1717 y 1723, de los dos volúmenes de la Perspectiva pictorum et architectorum.

No puede olvidarse, en este contexto, el muy significativo hecho de que el segundo volumen del Studio (Studio d'Architettura Civile sopra varj ornamenti di Cappelle, e diversi Sepolcri Tratti da più Chiese di Roma, colle loro Facciate Fianchi Piante, e Misure, 1711) fuese dedicado por Domenico de Rossi al cardenal Francesco Acquaviva d'Aragona, XIV duca d'Atri, nombrado, en 1717, embajador de España ante la Santa Sede por Felipe V y protector del Reino de España ya desde 1713. Precisamente el cardenal Acquaviva fue responsable, entre otros muchos asuntos relacionados con las artes y la arquitectura ${ }^{19}$, de la venida a España, en 1721, del pintor y académico Andrea Procaccini (1671-1734), que habría de jugar un papel primordial en la difusión de los volúmenes publicados por Domenico de Rossi, especialmente durante sus tareas como arquitecto responsable, entre 1724 y 1734 , de la ampliación del palacio de La Granja de San Ildefonso, debido a la iniciativa de Felipe $\mathrm{V}$ e Isabel de Farnesio y construida su primera versión por Teodoro Ardemans, entre 1721 y 1724 [7 a y b]. Puertas, ventanas, órdenes de arquitectura y otros ornatos exteriores de la colegiata y del palacio parecen sacados directamente de diferentes ejemplos de las láminas del Studio, desplegando las estampas de distintos modelos sobre los muros exteriores de su ampliación, como si se tratase de un tratado de arquitectura en piedra o, mejor, convirtiendo su construcción en una casi enciclopédica colección de estampas de detalles arquitectónicos de la arquitectura barroca romana ${ }^{20}$. Cabe añadir que Procaccini, académico de mérito

18 Conservada la edición mencionada del tratado de Pozzo, con su traducción manuscrita, en colección privada madrileña, pude darla a conocer en Delfín Rodríguez Ruiz (ed.), El Real Sitio de La Granja de San Ildefonso..., pp. 386-387, aunque aún espera un estudio detenido.

19 Recuérdese, entre ellos, que Francesco Acquaviva remodeló el Palacio de España en Roma e intervino, con Andrea Procaccini como mediador, en la llegada al palacio de La Granja de San Ildefonso de la célebre colección de escultura clásica de la reina Cristina de Suecia y de la colección de pinturas de Carlo Maratta, maestro de aquel. Sobre el primer asunto véase Alessandra Anselmi, II Palazzo dell'Ambasciata di Spagna presso la Santa Sede, Roma, Ed. Di Luca, 2001, pp. 107-110 y, sobre los segundos, los ensayos reunidos en Delfín Rodríguez Ruiz (ed.), El Real Sitio de La Granja de San Ildefonso. Sobre las fiestas organizadas en Roma por Francesco Acquaviva y por su sobrino Troiano Acquaviva, también embajador de España ante la Santa Sede, véase Sara Muniaín, "Arquitectura efímera y diplomacia. Los Acquaviva y la imagen celebrativa de la Monarquía española ante la Santa Sede (1717-1746)", en Reales Sitios, n. ${ }^{\circ} 166,2005$, pp. 62-77.

20 Sobre este característico uso de estampas de arquitectura por parte de Procaccini en el palacio de La Granja de San Ildefonso véanse Jörg Garms, "Referentes europeos de La Granja de San Ildefonso» y Delfín Rodríguez Ruiz, "El Palacio del Real Sitio de La Granja de San Ildefonso. Un retrato cambiante del rey", ambos en Delfín Rodríguez Ruiz (ed.), El Real Sitio de La Granja de San Ildefonso..., pp. 42-50 y 25-41, respectivamente. Posteriores aportaciones a este asunto pueden verse en Delfín Rodríguez Ruiz, El Palacio Real de La Granja de San Ildefonso, Madrid, Patrimonio Nacional-Iberdrola, 2004. 


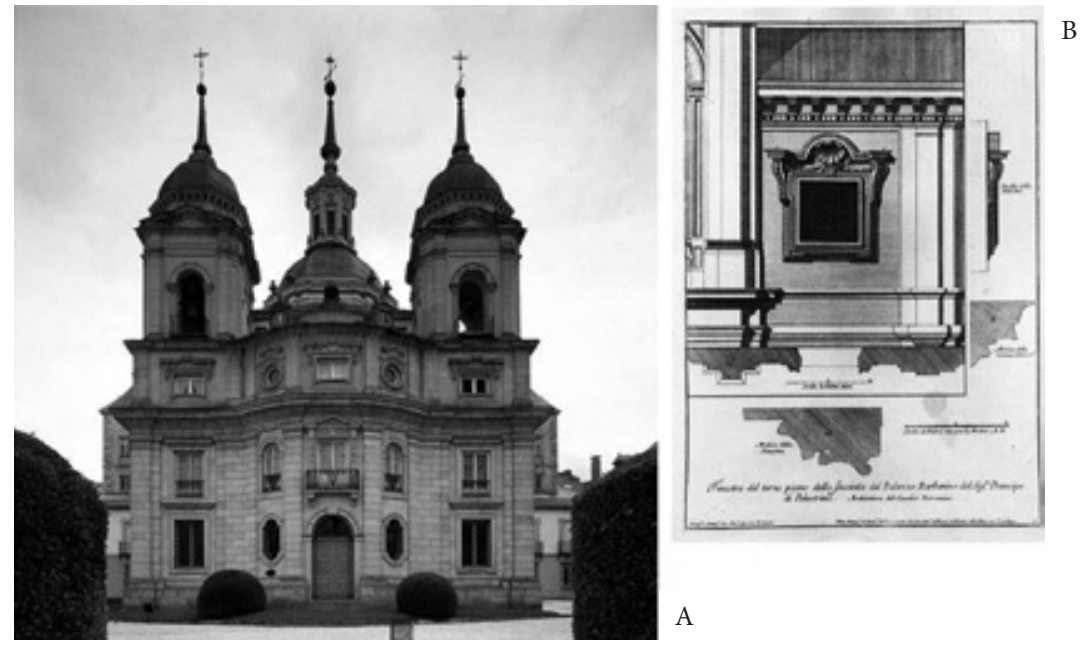

7. A) Real Sitio de La Granja de San Ildefonso (Segovia), Palacio. Fachada de la Colegiata. 1724-1734. Andrea Procaccini. B) Domenico de Rossi, Studio d'Architettura Civile, I (1702), Lám. 41: Finestra del terzo piano della facciata del Palazzo Barberini, de Francesco Borromini

de la Accademia di San Luca -precisamente desde 1711, fecha del segundo volumen del Studio-, lo fue elegido por Juvarra y Maratta, llegando a ser profesor en la misma entre 1715 y 1720 y compañero en tareas académicas de Alessandro Specchi, discípulo de Carlo Fontana y responsable del rigor en la representación y de la elección de edificios y detalles arquitectónicos de buena parte de las láminas del Studio de Domenico de Rossi. Recuérdese también que, posteriormente, Juvarra fue llamado para proyectar el Palacio Real Nuevo de Madrid en 1735, interviniendo además en el palacio de La Granja de San Ildefonso [8], un año después de la muerte de Procaccini, y, aunque murió pronto, en 1736, su magisterio, precisamente a través de Sacchetti y Ventura Rodríguez, sería muy duradero en la arquitectura española y en la Academia de San Fernando.

Los nombres mencionados, de Francesco Acquaviva y Juvarra a Procaccini y Specchi, ayudan a situar y comprender la temprana, consciente y poderosa influencia de la obra publicada por Rossi en la arquitectura española, a través, en primer lugar, del palacio de La Granja, y también, en segundo lugar, que, gracias a esa relación directa con la Monarquía hispánica y con las obras promovidas por Felipe $V$ e Isabel de Farnesio, puede explicarse su rápida difusión en ámbitos cortesanos y entre arquitectos, artistas, príncipes y aficionados en la 


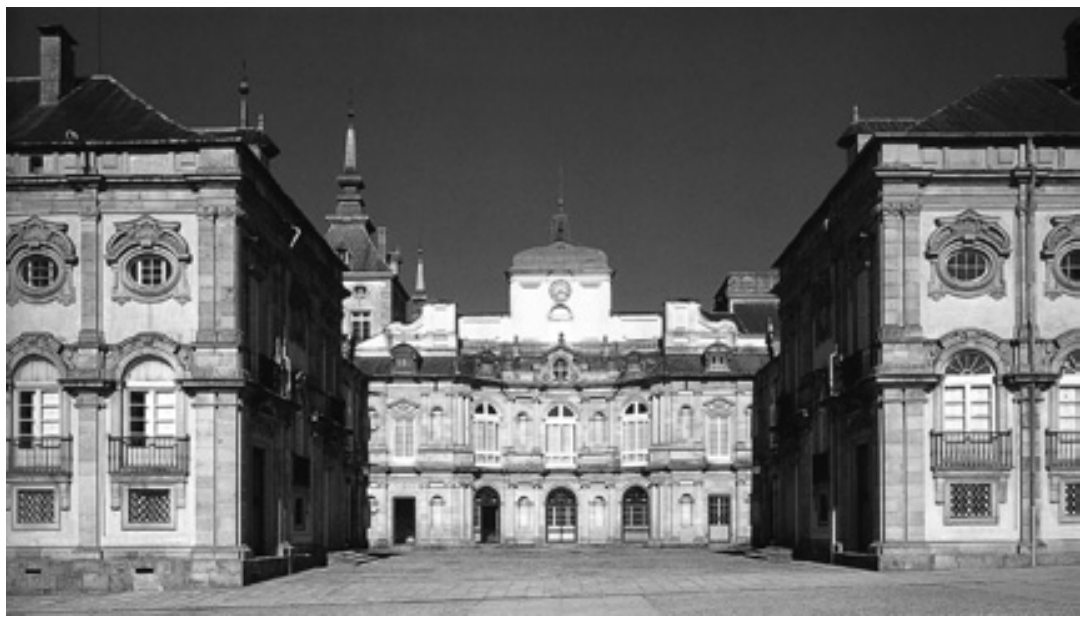

8. Real Sitio de La Granja de San Ildefonso (Segovia), Palacio. Patio de la Herradura, 1724-1734. Andrea Procaccini

España del siglo XVIII. Difusión no solo de modelos arquitectónicos e históricos del barroco romano, sino también de la estructura docente, de los sistemas de representación e intereses de la misma Accademia di San Luca, que acabarían configurando, junto con el modelo de la Academia de Arquitectura de París, la manera de apropiarse de esa tradición por parte de la propia Academia de BeIlas Artes de San Fernando a partir de mediados de siglo, con Felipe de Castro y Ventura Rodríguez, como se ha visto, como protagonistas indudables. Y esto, con independencia de que, en esos primeros años, fueran también maestros italianos vinculados a la construcción del Palacio Real Nuevo de Madrid los responsables primeros de la Academia, de Giovan Domenico Olivieri (1708-1762) ${ }^{21}$ a Sacchetti, aunque con mayor implicación el primero que el segundo. Si bien ya fue advertida por Anthony Blunt ${ }^{22}$ la evidente presencia del Studio de Domenico de Rossi en el lenguaje ornamental y molduras de puertas y ventanas y de otros fragmentos de arquitectura en el Palacio Real de Madrid, proyectado y construido por Sacchetti y que merecería un más detenido análisis.

21 Sobre Olivieri y los orígenes de la Academia en 1741-1743, véase María Luisa Tárrega, "Completo y formal inventario de cuanto Juan Domingo Olivieri compró para el servicio de la Academia de Bellas Artes de San Fernando", Academia, n. ${ }^{\circ} 43,1976$, pp. 5-22, aunque entre esas obras no se encuentra el Studio de Domenico de Rossi, que sin duda debía conocer.

22 Anthony Blunt, "Introduction», en la edición facsímil de Domenico de Rossi, Studio d'Architettura Civile, Farnborough, Gregg International, 1972, s.p. 
En cualquier caso, la importancia de Procaccini, entre 1722 y 1734, en la difusión del Studio entre artistas y arquitectos vinculados a la corte debió de ser fundamental, continuada luego por Sacchetti en el Palacio Real de Madrid. Parece lógico que, contemporáneamente e inmediatamente después, esos modelos pudieran estar presentes en las bibliotecas y en los proyectos y obras de nobles, artistas y arquitectos de origen italiano, responsables de buena parte de la actividad arquitectónica y escenográfica de la corte de Felipe V e Isabel de Farnesio, de Annibale Scotti (1676-1764), Giacomo Bonavia (1705-1759) ${ }^{23}$ o Vigilio Rabaglio (1711-1800)24 a Juvarra, Sacchetti, Olivieri o Giacomo Pavia (1699-1749), este último respetado profesor en la Academia de San Fernando en sus orígenes y tratadista ${ }^{25}$. Pero también lo es que maestros españoles, vinculados a los italianos en los Sitios Reales o simplemente contemporáneos de estos últimos, pudieran también, y precisamente por esos mismos motivos, tener acceso a las obras de la stamperia de Rossi y a los volúmenes del Studio. Ocurrió con arquitectos tan significados en la tradición barroca hispánica, de José Benito de Churriguera $(1665-1725)^{26}$ a Teodoro Ardemans ${ }^{27}$ (1661-1726) o Pedro de Ribera (1681-1742) ${ }^{28}$, trabajando los tres en ámbitos cortesanos o, genéricamente, en Madrid durante los primeros decenios del siglo XVIII. Si las obras del primero delatan, sin duda y en especial en algunos retablos, el conocimiento de una obra como Disegni di Vari Altari e Cappelle (1689-1691?), el último poseyó en su biblioteca el Insignium Romae Templorum (1684), mientras que Ardemans, que llegó a coincidir en sus últimos años de vida, entre 1722 y 1724, con Procaccini en las obras y ornamentación del palacio de La Granja, debió de conocer no solo las dos publicaciones

23 Sobre Scotti y Bonavía, con la bibliografía anterior, véase Delfín Rodríguez Ruiz, "Sobre el "apacible engaño de la vista». Arte y arquitectura en España durante la primera mitad del siglo XVIII" y "La arquitectura", ambos en Elena Santiago Páez (ed.), La Real Biblioteca Pública, 1711-1760. De Felipe Va Fernando VI, Madrid, Biblioteca Nacional, 2004, pp. 87-97 y 394-439, respectivamente.

24 Sobre Rabaglio véanse Antonio Bonet Correa (ed.), Arquitectura y ornamentos barrocos. Los Rabaglio y el arte cortesano del siglo XVIII, Madrid, Real Academia de Bellas Artes de San Fernando, 1997 y Carlo Agliati (ed.), Mastri d'arte del lago di Lugano alla corte dei Borbón di Spagna. Il fondo dei Rabaglio di Gandria, sec. XVIII, Bellinzona, Edizioni dello Stato del Cantone Ticino, 2010.

25 Sobre Pavía y su importancia y tratados, con la bibliografía previa, véase Delfín Rodríguez Ruiz, "Arquitectura y Academia...", pp. 222-227 y "Giovanni Bonavera y Giacomo Pavia», en Isabel García Toraño (ed.), Dibujos de Arquitectura y Ornamentación... Siglo XVIII, pp. 256-257.

26 Alfonso Rodríguez de Ceballos, Los Churriguera, Madrid, CSIC-Instituto Diego Velázquez, 1971 y, sobre los tres arquitectos mencionados, Beatriz Blasco, «Elogio del barroco castizo: Ardemans, Churriguera y Ribera", en Miguel Morán Turina (ed.), El arte en la corte de Felipe V, Madrid, Palacio Real de Madrid-Museo del Prado-Casa de las Alhajas, 2002, pp. 257-288.

27 Sobra la riquísima biblioteca de Ardemans, véase ahora, con la bibliografía anterior, Beatriz Blasco, "Una biblioteca "modélica». La formación libresca de Teodoro Ardemans (I) y (II)», en Ars Longa, núms. 5, 1994, y 7-8, 1996-1997, pp. 73-97 y 155-175, respectivamente.

28 Matilde Verdú, El arquitecto Pedro de Ribera (1681-1742), Madrid, Instituto de Estudios Madrileños, 1998. 
mencionadas, sino también los volúmenes del Studio, aunque no figuran en su extraordinaria biblioteca.

Especialmente interesante resulta, en este complejo viaje histórico del Studio d'Architettura Civile de Domenico de Rossi -y de otras obras de la stamperia romana- acompañando a Procaccini en su itinerar con la corte, el hecho de que el artista estuviera también presente en Sevilla, entre 1729 y 1733, durante el Ilamado Lustro Real ${ }^{29}$, años en los que Felipe $V$ e Isabel de Farnesio permanecieron en la ciudad. Esa estancia podría explicar, aunque no del todo, no solo la difusión de aquellos modelos entre pintores y arquitectos andaluces, desde arquitectos como Leonardo de Figueroa (ca. 1652-1730) ${ }^{30}$ al pintor Domingo Martínez (1688-1749), sino que, además, resulta extremadamente significativo que fuera precisamente en 1732 cuando, desde Sevilla, viajaron a Roma dos artistas que ya han sido citados por su importante significación en este contexto, me refiero al escultor Felipe de Castro y al pintor Preciado de La Vega, que conocieron sobradamente esos libros de estampas. Si es cierto que Leonardo de Figueroa -arquitecto fundamental en la época y autor de iglesias como la de San Luis de los Franceses o el Palacio de San Telmo, ambas en Sevilla- debió de conocer las obras de los De Rossi, y también el tratado de Andrea Pozzo con anterioridad a la presencia de Procaccini en la ciudad, lo que es indudable es que Domingo Martínez las poseyó en su biblioteca ${ }^{31}$.

Sin salir del ámbito de Andalucía, también debió de conocer la arquitectura de Roma moderna, Bernini y Borromini sobre todo, un arquitecto tan fascinante como Vicente Acero (1675/1685-1739), viajero por Italia a comienzos de los años diez del Setecientos según sus propias afirmaciones, lo que puede, además, constatarse en algunos de sus proyectos y obras. Aparejador, experto en el corte de cantería, arquitecto y teórico polémico, dio las trazas para la Catedral de Cádiz [9] en 1721, aunque en 1729 tuvo que abandonar las obras, después de una apasionante polémica con otros arquitectos como Leonardo de Figueroa o Pedro de Ribera. Acero $^{32}$, en ese proyecto y en otros en los que participó -Iglesia del Sagrario

29 Alfredo J. Morales, "Sevilla es Corte. Notas sobre el Lustro Real», en Delfín Rodríguez Ruiz, (ed.), El Real Sitio de La Granja de San Ildefonso..., pp. 172-181.

30 Jesús Rivas Carmona, Leonardo de Figueroa: una nueva visión de un viejo maestro, Sevilla, Arte Hispalense, 1994.

31 Sobre Domingo Martínez y su biblioteca véase ahora Alfonso Pleguezuelo y Enrique Valdivieso (eds.), Domingo Martínez en la estela de Murillo, Sevilla, Fundación El Monte, 2004 y especialmente la aportación, en ese catálogo, de Ana Aranda Bernal, "Apéndice documental», pp. 129-161.

32 Sobre Vicente Acero y su arquitectura y los modelos italianos de la misma véanse, entre otros, René Taylor, "La fachada de Vicente Acero para la Catedral de Cádiz", Archivo Español de Arte, n. ${ }^{\circ} 167,1969$, pp. 302-305; Rosario Camacho, Málaga Barroca. Arquitectura religiosa de los siglos XVII y XVIII, Málaga, Universidad de Málaga, 1981; Delfín Rodríguez Ruiz, "Álbum de Antonio García Reinoso», Elena Santia- 
de la Catedral de Granada, proyectos para la de Guadix [10] y la de Málaga, Sagrario de Cartuja del Paular (Segovia), proyecto para la Colegiata de San Sebastián de Antequera (Málaga) ${ }^{33}$, palacio para los duques de Medinaceli en el Puerto de Santa María ${ }^{34}$ (Cádiz) o la Fábrica de Tabacos de Sevilla- demostró conocer bien no solo la práctica de la arquitectura, sino la teoría, manejando modelos y tratados tanto franceses (D'Aviler, Perrault) como italianos (Alberti, Serlio, Palladio, Vignola, etc.). El borrominismo ${ }^{35}$ que observó, con razón, Taylor en su arquitectura y en su proyecto para la catedral de Cádiz pudiera proceder de su más que posible estancia en Roma contemplado directamente las obras del arquitecto de San Carlo alle Quattro Fontane y de Sant' Ivo alla Sapienza, pero también pudo tenerlo presente a través, precisamente, de las obras de Giovanni Giacomo de Rossi y Domenico de Rossi. Si es obvio que Acero no pudo tener acceso, para su catedral de Cádiz, porque aún no se habían publicado, a la edición de Sebastiano Giannini de los dos volúmenes dedicados a las obras de Borromini, Opera del Caval. Francesco Borromini cavata dei suoi originali cioè la Chiesa, e Fabrica della Sapienza di Roma (1720) y Operacioè I'Oratorio e Fabrica per I'Abitazione de PP. Dell'Oratorio di S. Filippo Neri di Roma $(1725)^{36}$, sí pudo, sin embargo, conocer tanto el Insignium Romae Templorum (1684) del primero, como los dos primeros volúmenes del Studio d'Architettura Civile (1702 y 1711) del segundo antes de volver a España, así como el tratado de Andrea Pozzo, Perspectiva Pictorum et Architectorum (Roma,

go Páez (ed.), Dibujos de Arquitectura y Ornamentación de la Biblioteca Nacional. Tomo I. Siglos XVI y XVII, Madrid, Biblioteca Nacional, 1991, pp. 313-363; Delfín Rodríguez Ruiz, "Tradición e innovación en la arquitectura de Vicente Acero", Anales de Arquitectura, Universidad de Valladolid, n. ${ }^{\circ} 4,1992$, pp. 422-423; Fernando Marías, "La Catedral de Cádiz de Vicente Acero: la provocación de la arquitectura crespa", Anuario del Departamento de Historia y Teoría del Arte, Universidad Autónoma de Madrid, vol. XIX, 2007, pp. 79-103; Delfín Rodríguez Ruiz, "Vicente Acero y Arebo, Proyecto para la fachada de la Catedral de Cádiz (ca. 1721)", en Isabel García Toraño (ed.), Dibujos de Arquitectura y Ornamentación de la Biblioteca Nacional. Tomo II. Siglo XVIII, Madrid, Biblioteca Nacional, 2009, pp. 3-4 y la fundamental aportación, con el inventario de su biblioteca, de Lorenzo Alonso de la Sierra y Francisco Javier Herrera "Del estudio en la teórica y del trabajo en la práctica. Observaciones sobre la formación, ideas y obra del arquitecto Vicente Acero", Anuario del Departamento de Teoría e Historia del Arte, Universidad Autónoma de Madrid, núms. XVI y XVII, 2004 y 2005, pp. 113-127 y 87-92, respectivamente.

33 Rosario Camacho, "Arquitectura y Colegiata», en Jesús Romero Benítez (ed.), La Real Colegiata de Antequera. Cinco siglos de arte e historia (1503-2003), Antequera, Archivo Histórico Municipal, 2004, pp. 121-154.

34 Sobre este proyecto, véase Raúl Romero Medina, «El palacio de los duques de Medinaceli y el proyecto inédito de Vicente Acero para el Puerto de Santa María", Revista de Historia de El Puerto, n. ${ }^{\circ} 33$, 2004, pp. 51-79.

35 Una primera aproximación a la influencia de Borromini en la arquitectura española puede verse en Alfoso Rodríguez de Ceballos, "Francisco Borromini y España», introducción a Giulio Carlo Argan, Borromini, Madrid, Xarait Ediciones, 1980, pp. 7-58.

36 Joseph Connors, "Sebastiano Giannini: Opus Architectonicum», en Bruno Contardi y Giovanna Curcio (eds.), In Urbe Architectus..., pp. 204-213 y Joseph Connors (ed.), Francesco Borromini. Opus architectonicum, Milán, II Polifilo, 1998. 
9. Vicente Acero, Proyecto para la Catedral de Cádiz. Alzado y planta de la fachada. Dibujo a pluma, tinta y aguadas, ca. 17211725 (Madrid, Biblioteca Nacional)

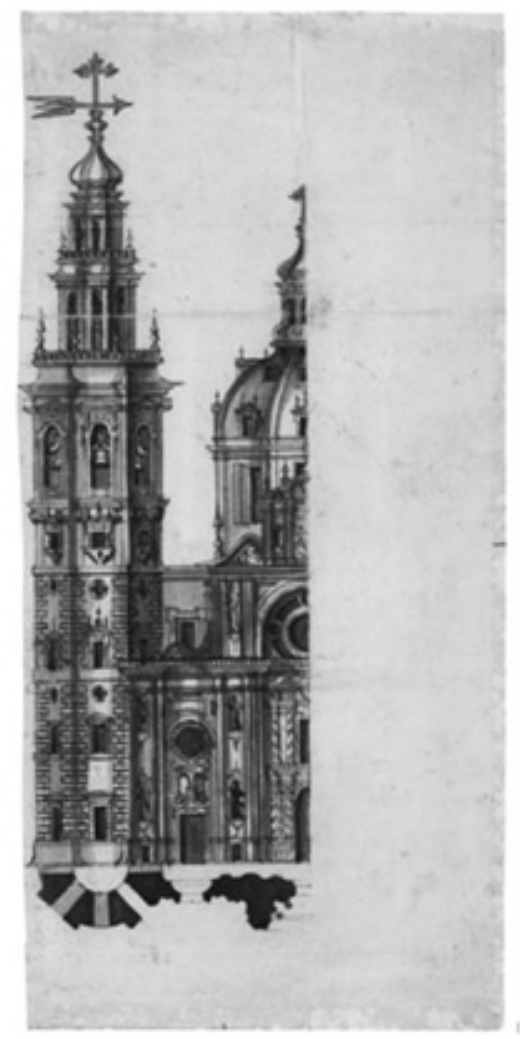

10. Guadix, Catedral. Puerta lateral de Santiago, ca. 1732. Vicente Acero

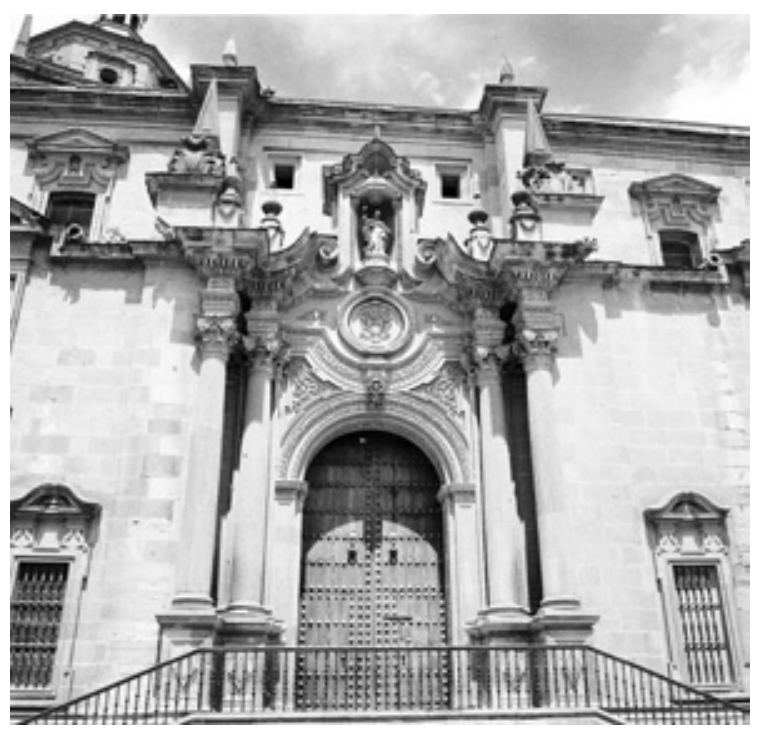


1693 y 1700), cuya influencia en España y en Hispanoamérica durante todo el siglo XVIII fue enorme entre pintores, arquitectos y artistas-tratadistas de tanta influencia como Antonio Palomino (1655-1726) ${ }^{37}$.

De hecho, la presencia del tratado de Pozzo casi siempre estuvo vinculada en España, en la primera mitad del Setecientos, a las obras mencionadas de Giovanni Giacomo y Domenico de Rossi, como si conformasen, junto con Disegni di Vari Altari e Cappelle (1689-1691?) también editada por el primero, pero con importante participación del segundo y de Specchi ${ }^{38}$, un repertorio visual privilegiado, un tratado aggiornato, de la moderna cultura arquitectónica romana. $Y$ se trata de modelos que fueron usados, como se ha visto, con casi rutinaria y canónica insistencia por artistas y arquitectos españoles e italianos que trabajaron en España, especialmente en la primera mitad del siglo y hasta bien entrados los años sesenta, durante los reinados de Felipe V (1683-1746), Fernando VI (17131759) y los comienzos del de Carlos III (1716-1788). Sirva como ejemplo, entre otros muchos, el de Diego Martínez de Arce (1703-1777) ${ }^{39}$, arquitecto de retablos que trabajó en el Palacio Real y en otros ámbitos cortesanos y al que se debe la arquitectura del espectacular retablo mayor (1763) de la iglesia de las Mercedarias de la Purísima Concepción de Madrid ("Las Góngoras») [11 a y b], inspirado ciertamente en el de la Cappella Alaleoni (1649-1650) de Gian Lorenzo Bernini, en la iglesia de los SS. Domenico e Sisto, en Roma, grabado en Disegni di Vari Altari e Cappelle (Lámina 20).

Por su parte, Vicente Acero poseía en su biblioteca, al morir en 1739, además de Vitruvio, Serlio, Palladio, Vignola o D’Aviler, el tratado de Andrea Pozzo y una descripción de Roma, mencionada tan genéricamente que podría tratarse de cualquier libro, aunque sabemos, por su arquitectura y por sus escritos, que su conocimiento de tratados y estampas de arquitectura era mucho mayor y no debe olvidarse su vinculación a centros urbanos, cabildos catedralicios y obras reales, en las que intervinieron también ingenieros militares, en los que pudo acceder a otros tratados y colecciones de estampas y, entre ellas, a las mencionadas de la stamperia de los Rossi, lo que explicaría no solo el borrominismo, sino

37 Antonio Palomino, El Museo pictórico y escala óptica, 2 vols., Madrid, Lucas Antonio de Bedmar, 1715 y Juan García, 1724, dedicado el primero a Isabel de Farnesio y el segundo a Luis I de Borbón. Sobre la presencia de Pozzo en su tratado véase el clásico estudio de Antonio Bonet Correa, "Láminas de "El museo pictórico y escala óptica" de Palomino", Archivo Español de Arte, n. ${ }^{\circ} 182,1975$, pp. 131-144. 38 Simona Ciofetta, "Alcune edizioni di architettura...", pp. 66-67.

39 Sobre este retablo de Martínez de Arce, con esculturas del académico Juan Pascual de Mena (17071784), estrecho colaborador de Felipe de Castro y Ventura Rodríguez, véase María Teresa Ruiz Barrera, "Una obra documentada de Diego Martínez de Arce y Juan Pascual de Mena en el convento madrileño de Las Góngoras", Estudios. Revista Trimestral de los Frailes de la Merced, n. ${ }^{\circ}$ 237, 2008, pp. 103-112. 
11. A) Madrid, Retablo mayor de la Iglesia de Mercedarias de la

Purísima Concepción («Las Góngoras»), 1763. Diego Martínez de Arce. B) Giovanni Giacomo de Rossi, Disegni di Vari Altari e Cappelle (1689-1690). Lám. 20: Cappella Alaleoni nella Chiesa di SS. Domenico e Sisto di Roma, de Gian Lorenzo Bernini
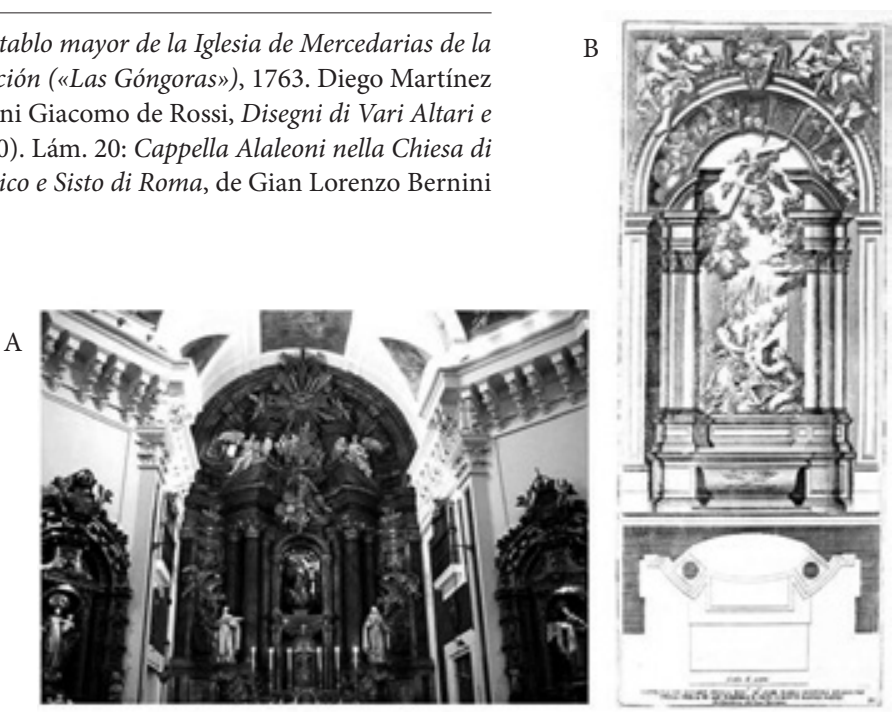

también otros modelos romanos (Sant'Ignazio, Cappella Sforza di Santa Maria Maggiore) de su lenguaje arquitectónico, especialmente en su proyecto para la Catedral de Cádiz, e incluso algunas soluciones tipológicas, entre berninianas y borrominianas (Sant'Andrea al Quirinale y San Carlo alle Quattro Fontane), como ocurre en su proyecto de Sagrario, no realizado, para la misma catedral o en la capilla del palacio de los duques de Medinaceli en el Puerto de Santa María, tampoco construido. Referencias todas ellas que pudo haber visto en la misma Roma o en el Insignium Romae Templorum o en algunos de los volúmenes del Studio d'Architettura Civile ${ }^{40}$. Es más, a comienzos de los años veinte, un ingeniero militar tan decisivo como Jorge Próspero Verboom (1665-1744), fundador del Real Cuerpo de Ingenieros, visitaba Cádiz e informaba positivamente del proyecto de Acero para la catedral y sabemos que en su biblioteca ${ }^{41}$ estaba, al menos, el primer volumen del Studio (1702) de Domenico de Rossi.

La circulación de modelos arquitectónicos y ornamentales, ya fuera por medio de estampas, dibujos o por la influencia misma de obras construidas, fueron sin duda muy frecuentes y habituales entre arquitectos españoles e italia-

40 Sobre la presencia de modelos sacados de la stamperia de G. Giacomo y Domenico de Rossi en Vicente Acero véanse los trabajos ya citados de René Taylor (1969), Delfín Rodríguez Ruiz (1992) y Fernando Marías (2007).

41 Juan Miguel Muñoz Corbalán, "La biblioteca del Ingeniero General Jorge Próspero Verboom», Academia, n. ${ }^{\circ} 80,1995$, pp. 343-362. 


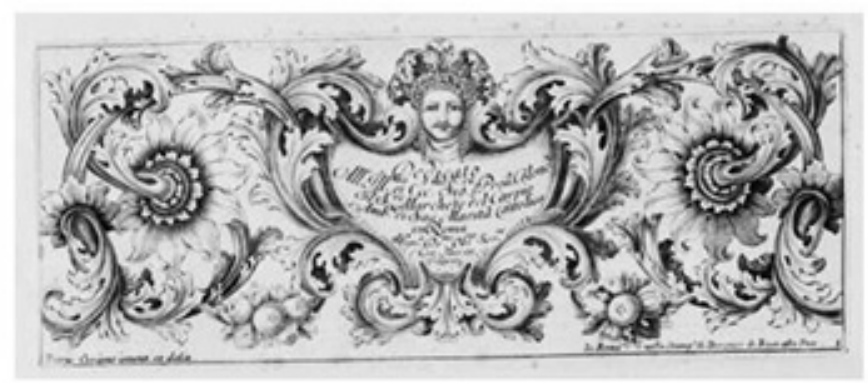

12. A) Pietro Cerino, Portada del ibro de ornatos dedicado al marqués del Carpio. En la Stamperia de Domenico Rossi alla Pace, 1710-1720. B) Pietro Cerino, Cartela y ornamentos decorativos, de la estampación realizada, antes de 1705, por Gio. Marco Paluzzi, grabada por Nicola Billy

nos en la época de Acero, incluidos los napolitanos y sicilianos ${ }^{42}$, además de los conocidos vínculos con Roma. En este sentido, las relaciones entre la stamperia de los Rossi y la cultura hispánica fueron extraordinariamente importantes, no solo por medio de sus ediciones de estampas arquitectónicas, sino también por sus grabados de planos cartográficos de reinos de España o de repertorios ornamentales. A propósito de estos últimos, cabe recordar cómo Domenico de Rossi, entre 1710 y 1720, volvió a estampar -lo que era práctica habitual- una magnífica colección de ornamentos en forma de roleos, cartuchos, cartelas y tarjas que, en número de doce grabados, ya había sido editada, posiblemente a finales del siglo XVII y, con seguridad, hacia 1705, por otro impresor romano como Gio. Marco Paluzzi. El interés de ese repertorio, inventado y dibujado por Pietro Cerino ("Petrus Cerinus invent. et delin.») y grabado por Nicola Billy ( Nicollo Billy Sculp. Romae $1 »)$ reside también en el hecho de que la primera estampación de Paluzzi fue dedicada -lo que ha pasado desapercibido hasta ahora- al marqués del Carpio (Madrid, 1629-Nápoles, 1687), extraordinario coleccionista y embaja-

42 Sobre estos temas, véase Marco Rosario Nobile, Salvatore Rizzo y Domenica Sutera (eds.), Ecclesia Triumphans. Architetture del Barroco siciliano attraverso i disegni di progetto. XVII-XVIII secolo, Palermo, Ed. Caracol, 2009. 
dor español ante la Santa Sede (1677-1682) y virrey de Nápoles (1683-1687) ${ }^{43}$. La dedicatoria del libro de ornatos confirma que debió de ser estampado, en una primera ocasión, en torno a 1680, cuando Carpio era aún embajador en Roma, ya que el título dice así: Dedicato / All' III.mo Ecc.mo Sig.re e Pron. Colend / II S.re Marchese del Carpio / Amb.re di Sua Maesta Cattolica / in Roma / I sum.o De. mo Obl. mo Ser.re / Gio: Marco / Paluzzi. Sin embargo, una de las estampas -la numerada "5»- vinculadas a esa edición lleva la fecha incompleta de "170...", aunque no es improbable que el citado impresor hubiera realizado tiradas anteriores, entre 1680 y la primera década de 1700. Domenico de Rossi volvió a estampar ${ }^{44}$ esta colección de grabados entre 1710 y 1720 , al tiempo que estaba empeñado en la edición del Studio, lo que también indica el interés comercial y la fortuna entre orfebres y artesanos, así como entre arquitectos y entalladores, de repertorios ornamentales semejantes, especialmente en ámbitos hispánicos, como puede confirmarse con obras semejantes estampadas en España siguiendo ese tipo de modelos, de Churriguera al fundamental de fray Matías de Irala, Método sucinto y compendioso en cinco simetrías apropiadas a los cinco órdenes de arquitectura adornada con otras reglas útiles, publicado en Madrid, entre 1730 y $1739^{45}$, que no es imposible que hubiera conocido la colección ideada por Pietro Cerino, tantas veces estampada en Roma [12 a y b].

De Pietro Cerino, inventor y dibujante de los mencionados motivos ornamentales, así como de otros repertorios parecidos, especialmente útiles para orfebres y joyeros, no se tienen muchas noticias, si es que no cabe identificarlo con el ornamentista, escenógrafo y arquitecto de obras efímeras del mismo nombre ${ }^{46}$, activo en Messina a finales del siglo XVII y durante el primer tercio del siglo XVIII, coincidiendo con la primera actividad de Filippo Juvarra en la ciudad, especialmente con la excusa de las arquitecturas efímeras que realizó, en 1701, en honor precisamente de Felipe V. En todo caso, el lenguaje de Cerino, como puede comprobarse en su máquina efímera para el altar mayor de la catedral de

43 Sobre el marqués del Carpio coleccionista, véase el fundamental estudio de Leticia de Frutos, El Templo de la Fama. Alegoría del Marqués del Carpio, Madrid, Fundación Caja Madrid-Fundación Arte Hispánico, 2009.

44 Con respecto a la primera estampación de Billy y Paluzzi, la edición de Rossi cambia solo en la inscripción de la portada, en la parte inferior derecha, en la que "Nicollo Billy Sculp. Romae 1" ha sido sustituida por «In Roma nella Stampa. di Domenico Rossi alla pace 1 ».

45 Véase, al respecto de esta obra y del uso de colecciones de motivos ornamentales de este tipo, el estudio de Antonio Bonet Correa, "Fray Matías de Irala, grabador y tratadista del siglo XVIII", Figuras, modelos e imágenes en los tratadistas españoles, Madrid, Alianza ed., 1993, pp. 250-316.

46 Véase, en relación a estos temas, Monica Craparo, "Un apparato festivo tra tradizione e neo-borrominismo: Pietro Cerino 1728", Lexicon. Storie e architettura in Sicilia e nel Mediterraneo, n. ${ }^{\circ} 1,2005, \mathrm{pp}$. 41-46. 
Messina, levantada, en $1728^{47}$, con motivo de las ceremonias festivas celebradas en honor de la Madonna della Sacra Lettera, se mantuvo fiel a tradiciones tardobarrocas próximas a las que usaban contemporáneamente arquitectos españoles como Churriguera, Ribera o el propio Acero en sus proyectos y obras.

La relación con los tratados clásicos de arquitectura, pero sobre todo con el uso de repertorios de estampas de edificios, fundamentalmente romanos, como los mencionados de la stamperia De Rossi -habitualmente acompañados, como se ha visto, por la obra de Andrea Pozzo, por el inevitable tratado de Domenico Fontana, Della Trasportatione dell'Obelisco Vaticano, en sus dos ediciones de 1590 y 1604, así como por el Templum Vaticanum (1694) de Carlo Fontana-, fue, en efecto, muy habitual entre arquitectos y maestros de obras, aparejadores y algunos alarifes durante la primera mitad del siglo XVIII, vinculados o no a obras cortesanas. No era infrecuente, entre maestros menores, de los tópicamente llamados "castizos" 48 -manera hispánica no solo en la época del barroco, sino ampliada, no sin polémicas historiográficas, a invariantes propios de una respuesta local, atenta a tradiciones nacionales, frente a los prestigiosos modelos italianos y franceses, fundamentalmente-, que pudieran también tener acceso a esas imágenes, ya fuera con la excusa de discusiones o informes sobre determinados proyectos o en intervenciones y asesoramientos de obras concretas, así como en conversaciones profesionales.

Se trata de libros y tratados que, una veces en manos de arquitectos españoles y otras propiedad de italianos o franceses que trabajaban en la corte o en obras de mecenazgo regio, tantas veces llamados también por la Iglesia para sus obras y proyectos, fueron consultados con relativa frecuencia, incluso por maestros de obras, como modelos o como respuestas a soluciones concretas. Al respecto, es enormemente significativo el caso de un maestro menor como Juan García Berruguilla ${ }^{49}$, autor de un tratado titulado Verdadera práctica de las resoluciones de la Geometría (1747), en el que se autodefine a sí mismo como arquitecto "peregrino» por sus muchos viajes por España y Portugal y parece

47 La estampa que reproduce la arquitectura efímera de Cerino está firmada como «Petrus Cerinus», en Giovanni Ortolano, Trionfo di fede e d'ossequio guidato sul cocchio della magnificenza overo distinto ragguaglio delle pompe festive apparecchiate quest'anno 1729 dallla Nobile, fedelissima ed esemplare città di Messina in onore della sua Benedetta Protettrice Maria della Sacra Lettera, Messina, 1728.

48 Véase, al respecto, un breve estado de la cuestión en Delfín Rodríguez Ruiz, "Madrid al tempo dei Rabaglio. Cultura architettonica e immagine della città», en Carlo Agliati (ed.), Maestri d'arte del lago di Lugano..., pp. 144-167.

49 Sobre Juan García Berruguilla y su relación con los proyectos de Vicente Acero para Cádiz y Antequera véase ahora con la bibliografía, anterior, Fernando Marías, "Vicente Acero: de Granada a Cádiz, de Málaga a Antequera", en Alfredo J. Morales (ed.), Actas del Congreso Internacional Andalucía Barroca. I. Arte, Arquitectura y Urbanismo, Sevilla, 2009, pp. 99-114. 
que también por Rusia. Según afirma en su tratado, participó como maestro práctico en construcción en numerosos proyectos, habiendo mantenido contactos con arquitectos vinculados a las obras reales como Teodoro Ardemans, Giovanni Battista Sacchetti, Giacomo Bonavera o Giacomo Pavia, entre otros muchos. También fue consultado y trabajó en diferentes obras en Madrid, Salamanca, Granada o Antequera. En esta última ciudad lo hizo, precisamente, para la Colegia de San Sebastián, la misma para la que había presentado un proyecto Vicente Acero, arquitecto con el que ya había colaborado también en la maqueta de la catedral de Cádiz, entre 1724 y 1731, lo que debió facilitar su conocimiento de estampas de la arquitectura romana, ya fueran debidas a la stamperia De Rossi o estudiando la misma obra de Carlo Fontana sobre San Pedro del Vaticano.

Así, en relación al uso de estampas entre arquitectos -aun cuando no poseyeran en propiedad esos libros-con el fin de encontrar o comentar soluciones constructivas $u$ ornamentales, bien vale una significativa observación contenida en su tratado, en el que escribe, al respecto de la primacía de sus conocimientos prácticos y de construcción frente a los modelos que podían contemplarse en las estampas, por muy prestigiosos que fuesen, que: "[...] y à postreros del año de 1742, enseñándome un Libro de las Obras grandes de Roma los Boloñeses, Bonaveras, y Don Santiago Pavia, les dixe era falso un perfil de Medianaranja, à lo que se riyeron mucho, y me dixeron que era el Templo de San Pedro, se sabe lo que sucediò de allì a poco ${ }^{50}$. Berruguilla se refiere, en su observación sobre la falsedad de la cúpula, frente a las risas de sus interlocutores italianos, a los problemas y debates que sobre la cúpula de San Pedro del Vaticano se suscitaron en 1742 y en los que intervinieron arquitectos y matemáticos tan importantes como Luigi Vanvitelli, Giovanni Poleni, François Jacquier o Ruggero Boscovich, entre otros muchos. Asunto este que proporciona una idea muy elocuente de la rapidez con la que circulaban noticias relativas a proyectos y obras en la cultura arquitectónica española en esos años. Es muy posible que la sección de la cúpula de San Pedro del Vaticano, que los Bonavera o Pavia enseñaron a Berruguilla en ese libro de las Obras grandes de Roma, fuera alguna de las estampas del Insignium Romae Templorum (1684) o del Templum Vaticanum (1694) de Carlo Fontana, muy posiblemente del primero, si se tiene en cuenta el título genérico mencionado.

Arquitecto práctico y peregrino, viajero por edificios de distintos lugares y por libros e ideas, debatidos con importantes arquitectos cortesanos, de Arde-

50 Juan García Berruguilla, Verdadera práctica de las resoluciones de la Geometría, sobre las tres dimensiones para un perfecto architecto..., Madrid, Imprenta de Lorenzo Francisco Mojados, 1747. La afirmación transcrita se encuentra en el Prólogo al Lector, s.p. 
mans a Vicente Acero, de Sacchetti, arquitecto del Palacio Real Nuevo de Madrid $^{51}$, a Giacomo Pavia, escenógrafo y arquitecto, profesor, como se ha visto, de perspectiva y arquitectura en la Junta Preparatoria de la Academia de Bellas Artes de Madrid desde 1744 y académico de la de Bolonia, García Berruguilla da una idea cabal de la manera en la que las noticias e imágenes de edificios y construcciones de diferentes lugares circulaban entre los profesionales, desde los arquitectos a los alarifes y maestros de obras.

Sin embargo, no cabe duda que fue con Procaccini y en el palacio del Real Sitio de La Granja de San Ildefonso donde puede comprobarse el comienzo del recorrido más afortunado de los tres volúmenes de Rossi, influyendo en artistas y aficionados y atrayendo la atención de príncipes y nobles, como puede deducirse, entre los primeros, por el rico repertorio, usado en el palacio, de ventanas, puertas y molduras de las fachadas o en algunas arquitecturas fingidas de Bonavia, que confirman la presencia reiterada del repertorio ornamental contenido en el Studio d'Architettura Civile ${ }^{52}$, así como ejemplos sacados del tratado de Andrea Pozzo, Perspectiva pictorum et architectorum (1693 y 1700), posiblemente dos de las fuentes italianas fundamentales de la arquitectura española y cortesana de la primera mitad del siglo XVIII, especialmente el tratado del jesuita, incluso para el uso pintado o construido del "frontón invertido» ${ }^{53}$, que también usó Vicente Acero en la catedral de Cádiz, ya fuera procedente de Pozzo o de algunos ejemplos del Studio de Domenico de Rossi.

De la atracción de príncipes y nobles, muchos de ellos vinculados a la historia misma del palacio de La Granja, por los volúmenes de Domenico de Rossi, pueden dar idea algunas bibliotecas importantes como la privada de la reina Isabel de Farnesio (1692-1766), inventariada a su muerte en $1766^{54}$ y especialmente rica en libros y tratados de arquitectura y, sobre todo, en repertorios de estampas y colecciones de vistas de ciudades y edificios. Bibliófila y lectora apasionada, como el propio Felipe $V$, con el que contrajo matrimonio en 1714, reunió una

51 Francisco Javier de la Plaza, Investigaciones sobre el Palacio Real Nuevo de Madrid, Valladolid, Universidad de Valladolid, 1975.

52 Sobre el uso del Studio de Domenico de Rossi en por Andrea Procaccini en la ampliación del Palacio de La Granja de San Ildefonso he tratado en Delfín Rodríguez Ruiz (ed.), El Real Sitio de La Granja de San Ildefonso. Retrato y escena del Rey..., pp. 37-40 y 378-379, así como en El Palacio Real de La Granja de San Ildefonso.

53 Antonio Bonet Correa, "El frontón invertido», Bracara Augusta, vol. XXVII, 1973, pp. 63-87.

54 La biblioteca de Isabel de Farnesio y su inventario de 1766 en La Granja de San Ildefonso pudimos darlos a conocer con motivo de la exposición sobre ese Real Sitio. Véanse, al respecto, María Luisa López Vidriero, "Inventario de la Librería de Isabel de Farnesio", Delfín Rodríguez Ruiz (ed.), El Real Sitio de La Granja de San Ildefonso..., pp. 433-435 y Elena Santiago Páez, "La Biblioteca de Isabel de Farnesio", en Elena Santiago Páez (ed.), La Real Biblioteca Pública, 1711-1760. De Felipe V a Fernando VI, Madrid, Biblioteca Nacional, 2004, pp. 269-284. 
biblioteca particular verdaderamente excepcional, con numerosos libros dedicados y, entre ellos, varios repertorios de vistas de Roma como el de Bonaventura Obervecke, Stampe degli avanzi dell'Antica Roma (1739), edición especial publicada en Londres a expensas de Giacomo Amigoni (1680-1752) ${ }^{55}$, y los de Giuseppe Vasi, Delle Magnificenze di Roma Antica e Moderna (1754), cuya dedicatoria se debió, sin duda, al hecho de que Carlos III, rey de Nápoles en ese momento, le hubiese autorizado al grabador y editor -con el que colaboró el joven Giovanni Battista Piranesi- a instalarse, desde 1748, en el propio palacio Farnese de Roma. De la stamperia De Rossi, la reina poseía numerosas obras (desde los repertorios de Falda a Pietro Ferrerio, de Bellori a Montano) y no podían faltar, por supuesto, los tres volúmenes del Studio d'Architetura Civile -acompañados como era casi obligado en tantas otras bibliotecas del Insignium Romae Templorum (1684)-, así como su correlato florentino que no es otro que el tratado, también en tres volúmenes, de Ferdinando Ruggieri, Studio d'Architettura Civile sopra gli ornamenti di porte, e finestre...tratte da alcune fabbriche insigni di Firenze (Florencia, $1722,1724$ y 1728$)^{56}$, presentes ambos repertorios, durante el siglo XVIII, casi como parte de un programa conceptual, en muchas bibliotecas españolas de arquitectos, artistas y aficionados, además de estarlo en la de la propia Real Academia de Bellas Artes de San Fernando.

El Studio de Domenico de Rossi también fue adquirido para la Real Biblioteca por Felipe $\mathrm{V}$ y formó parte de las de sus hijos, del Infante don Luis Antonio de Borbón al futuro Carlos IV ${ }^{57}$ (1748-1819), Príncipe de Asturias entre 1760 y 1788, quien en 1775 ya poseía, encuadernados ese mismo año por Antonio de Sancha, librero habitual del Príncipe, varias obras de Giovanni Battista Piranesi, Vedute di Roma, (1748-1774) y De romanorum magnificentia et architectura (1761), así como /l Tempio Vaticano (1694), de Carlo Fontana, Delle Magnificenze di Roma antica e moderna (1747-1761, 3 vols.), de Giuseppe Antonio Vasi o Castelli, e Ponti (1743), de Niccola Zabaglia ${ }^{58}$, pero, sobre todo, en esa fecha, poseía

55 Sobre esa edición de Amigoni dedicada a Isabel de Farnesio, véanse Elena Santiago Páez, «La Biblioteca de Isabel de Farnesio», pp. 275-277 y Delfín Rodríguez Ruiz, "La arquitectura cortesana y los Sitios Reales", en Elena Santiago Páez (ed.), La Real Biblioteca Pública..., p. 428.

56 La Biblioteca Nacional de Madrid conserva, inédito, un dibujo anónimo, posiblemente italiano, sacado de una estampa del repertorio de Ruggieri. Me refiero al n. ${ }^{\circ} 8475$ de la mencionada institución y que copia la estampa . $^{\circ} 66$ del primer volumen (1722), representando la destruida "Porta della Compagnia di San Giuseppe», obra de Matteo Nigetti. Véase, al respecto, Luciano Berti, "Matteo Nigetti", I y II, Rivista d'Arte, n. ${ }^{\circ} 26$ y 27, 1950 y 1951-1952, pp. 157-184 y 93-106, respectivamente.

57 Sobre la biblioteca, en 1782, del futuro Carlos IV, siendo Príncipe de Asturias, véase el cuidado estudio de María Luisa López Vidriero, Specvlvm Principvm. Nuevas lecturas curriculares, nuevos usos de la Librería del Príncipe en el Setecientos, Madrid, Instituto de Historia del Libro y de la Lectura, 2002.

58 Una edición facsímil puede verse en Niccola Zabaglia, Castelli e Ponti (Roma, Stamperia Pagliarini, 1743), Madrid, Instituto Juan de Herrera, 2005, con Estudio Introductorio de Juan Bordes, pp. 1-30. 
varias obras publicadas por la stamperia de los De Rossi y, entre ellas, las de G. Battista Falda, Giovanni Battista Montano y Pietro Ferrerio y, fundamentalmente, las tres que, como en un proyecto intencionado, comenzado por Giovanni Giacomo de Rossi y continuado por Domenico de Rossi, estuvieron presentes en tantas bibliotecas de príncipes, nobles, arquitectos y academias del siglo XVIII, incluidas las españolas: Insignium Romae Templorum (1684), Disegni di Vari Altari e Cappelle (1689-1691?) y los tres volúmenes, que ahora nos ocupan, del Studio d'Architettura Civile (1702, 1711 y 1721). Es más, como para completar el elenco casi programático descrito, en esa misma remesa de libros encuadernados por Sancha, en 1775, para el Príncipe de Asturias ${ }^{59}$, se encontraban también Ios cuatro volúmenes de Ferdinando Ruggieri, Scelta di architettura antiche e moderne della città di Firenze, en su segunda edición, de 1755, ampliada por Giuseppe Bouchard. Se trata de libros y ediciones que se conservan hoy en la Real Biblioteca del Palacio Real de Madrid y que muestran el interés del que habría de ser, a partir de 1788, Carlos IV, por las artes y la arquitectura ya desde sus años de formación, lo que viene avalado, además, por el testimonio de dos dibujos de arquitectura de su mano conservados hoy en la Biblioteca Nacional ${ }^{60}$ y en la Real Academia de Bellas Artes de San Fernando ${ }^{61}$. Cabe añadir que prácticamente todos los volúmenes encuadernados por Sancha fueron encargados, en 1773, por el Príncipe de Asturias al embajador español en Roma, José Moñino, Conde de Floridablanca ${ }^{62}$, que tanta importancia habría de tener, a su vuelta a España, tanto en términos políticos como artísticos y arquitectónicos, siendo el responsable del encargo a Juan de Villanueva (1739-1811) del edificio que, pasado el tiempo, habría de ser el del Museo del Prado63, en Madrid.

Siendo extremadamente interesante el listado de libros mencionado en la biblioteca de un futuro monarca como Carlos IV, cabe añadir que la elección de

59 Véase el listado, descripción y localización de esas obras en María Luisa López Vidriero, Specvlvm Principvm, pp. 158-161.

60 Delfín Rodríguez Ruiz, "Carlos de Borbón, Proyecto de fachada (1763)», Dibujos de Arquitectura y Ornamentación de la Biblioteca Nacional, Tomo II, Siglo XVIII, Madrid, Biblioteca Nacional, 2009, pp. 22-23.

61 Al respecto del dibujo de la Academia de San Fernando, véanse Fernando Chueca Goitia y Carlos de Miguel, La vida y las obras de Juan de Villanueva, Madrid, Gráficas Carlos-Jaime, 1949, pp. 241-242 y Claude Bédat, La Real Academia de Bellas Artes de San Fernando, 1744-1808, Madrid, Fundación Universitaria Española, 1989, p. 149, (Lámina 9). Sobre Carlos IV y las artes véase ahora, con la bibliografía anterior, Javier Jordán de Urríes y José Luis Sancho (eds.), Carlos IV. Mecenas y coleccionista, Madrid, Patrimonio Nacional, 2009.

62 El listado de libros del encargo, en 1773, del futuro Carlos IV a su embajador en Roma, José Moñino, fue publicado por Jesús Urrea, Relaciones Artísticas Hispano-Romanas en el siglo XVIII..., pp. 119-120. 63 Véase ahora, con la bibliografía anterior, Pedro Moleón, El Museo del Prado. Biografía del edificio, Madrid, Museo Nacional del Prado, 2011. 
los mismos no era fortuita, sino casi programática, tanto en la educación de un príncipe como en otras bibliotecas nobiliarias y de intelectuales y altos cargos de la administración de la monarquía y de la Iglesia, además de serlo, obviamente, entre artistas $y$ arquitectos que trabajaban para ellos y que intentaban consolidar un nuevo gusto avalado por la historia misma de la arquitectura, especialmente la romana, tanto la antigua como la moderna. Es más, el propio librero, encuadernador e impresor Antonio de Sancha (1720-1790), que había encuadernado los libros señalados para el Príncipe de Asturias, incluidos los de Domenico de Rossi, era también el librero de la Real Academia de San Fernando desde 1757, es decir, casi desde su fundación formal en 1752, llegando a presentar, en 1764, a la institución un riquísimo lote de libros franceses, después de un viaje a París ${ }^{64}$. Libros de estampas y tratados de arte y arquitectura que ayudaron a fijar el doble modelo francés y e italiano, aunque fundamentalmente romano, de la arquitectura española de esos años. Y recuérdese, por ejemplo, que el propio Sancha tenía una tertulia en la trastienda de su taller de impresor y encuadernador que frecuentaban artistas e ilustrados de tanta importancia en la España del siglo XVIII como Eugenio Llaguno -autor de una imprescindible historia de la arquitectura española, añadida por Juan Agustín Ceán Bermúdez y publicada ya a comienzos del siglo XIX ${ }^{65}$-, o Vicente García de la Huerta, políticos y ministros como Campomanes o el Conde Aranda -cuya relación con el arquitecto José de Hermosilla fue muy estrecha ${ }^{66}$ - y artistas como Manuel Salvador Carmona o Luis Paret-pintor pensionado en Roma, entre 1763 y 1766, por el infante Luis Antonio de Borbón, mecenas también de Francisco de Goya y de Ventura Rodríguez-, que llegaría a ocupar un papel destacado en la Comisión de Arquitectura de la Academia a finales de siglo.

64 Claude Bédat, La Real Academia de Bellas Artes de San Fernando..., pp. 306-310.

65 La historia de los arquitectos y de la arquitectura española de Eugenio Llaguno estaba muy adelantada, casi acabada, en los años sesenta del siglo XVIII, y como manuscrito circuló entre los intelectuales y arquitectos vinculados a la Academia de San Fernado, de Antonio Ponz a Nicolás de Azara. Obra de referencia fundamental, no fue publicada, con adiciones de Juan Agustín Ceán Bermúdez, hasta comienzos del siglo XIX con el título de Eugenio Llaguno y Amirola, Noticia de los arquitectos y arquitectura de España desde su restauración..., Madrid, Imprenta Real, 1829, 4 vols. El manuscrito de Llaguno pudo consultarlo y usarlo para sus noticias sobre arquitectos españoles, gracias a Azara, el mismísimo Francesco Milizia, según afirma en la cuarta edición, de 1785, de sus Memorie degli architetti antichi e moderni, Bassano, Remondini, 1785, vol. I, pp. 259-260. Edición que Milizia dedicó a Nicolás de Azara. Véase al respecto Delfín Rodríguez Ruiz, "José Ortiz y Sanz: "atención y pulso" de un traductor», introducción a Vitruvio, Los Diez Libros de Architectura, edición y notas de José Ortiz y Sanz (1787), Madrid, Ed. Akal, 1987, pp. 7-33.

66 Al respecto, véase Delfín Rodríguez Ruiz y Carlos Sambricio, «El conde de Aranda y la arquitectura española de la llustración", en José Ferrer Benimeli (ed.), El Conde de Aranda, Zaragoza, Diputación de Aragón, 1998, pp. 149-171. 
Sirva la mención de esa tertulia en el taller de un librero, que difundió la obra de la stamperia de los De Rossi en la España de su época y en la que coinciden artistas, escritores ilustrados y nobles vinculados todos ellos a la Real Academia de Bellas Artes de San Fernando, para hacernos una idea de la recepción del Studio, entre otras publicaciones, en la cultura española de la segunda mitad del siglo XVIII. Piénsese, en este sentido, que en una tertulia tan célebre en Madrid, durante los años sesenta y setenta, como la de Pedro Rodríguez Campomanes, también coincidían los mismos artistas y otros muy representativos, especialmente el arquitecto Ventura Rodríguez y el escultor Felipe de Castro, además de Anton-Rafael Mengs durante su estancia en España, conocedores y usuarios todos ellos de las obras publicadas por los De Rossi y, especialmente, del Studio d'Architettura Civile de Domenico. Es más, cabe señalar en este momento que con motivo de la entrada en Madrid ${ }^{67}$, en 1760, de Carlos III, procedente de Nápoles para asumir la corona (lo que haría entre 1759 y 1788), de la Monarquía Hispánica, las fiestas que se organizaron y las arquitectura y ornamentos efímeros que se levantaron con esa excusa fueron realizadas por Ventura Rodríguez (1717-1785) en lo relativo a la arquitectura y por Felipe de Castro (ca. 1711-1775) para la escultura, ornatos, trofeos y bajorrelieves [13], mientras que el poeta y dramaturgo Vicente García de la Huerta (1734-1787) fue responsable de las transcripciones latinas y el historiador, erudito y futuro Ministro de Hacienda con Carlos III, Pedro Rodríguez Campomanes (1723-1802) fue el autor intelectual de la "invención de asuntos históricos, su distribución, y las Inscripciones", todos ellos conocedores, además, de la Roma moderna ilustrada por Domenico de Rossi en su Studio, así como de otras obras de la stamperia como las ya mencionadas Insignium Romae Templorum o Disegni di Vari Altari e Cappelle, y participantes en las tertulias mencionadas. Se convirtieron así, en conscientes responsables de la renovación del gusto en la arquitectura española cortesana y académica que se consolida a partir de los años centrales del siglo XVIII.

Podría decirse que aquella fiesta y sus arquitecturas y ornatos -cuyos lenguajes están tan próximos al de muchas de las arquitecturas representadas en los volúmenes de Giaovanni Giacomo y Domenico de Rossi-, descritos en la Relación de los arcos, inscripciones, y ornatos de la carrera por donde ha de passar el Rey Nuestro Señor D. Carlos III en su entrada pública ${ }^{68}$, publicada en 1760 , supuso no solo la confirmación de un modelo canónico que acabaría con-

67 Carlos Sambricio (ed.), Carlos III. Alcalde de Madrid, Madrid, Imprenta Municipal, 1988.

68 Impreso en Madrid, Joachim Ibarra, 1760. 


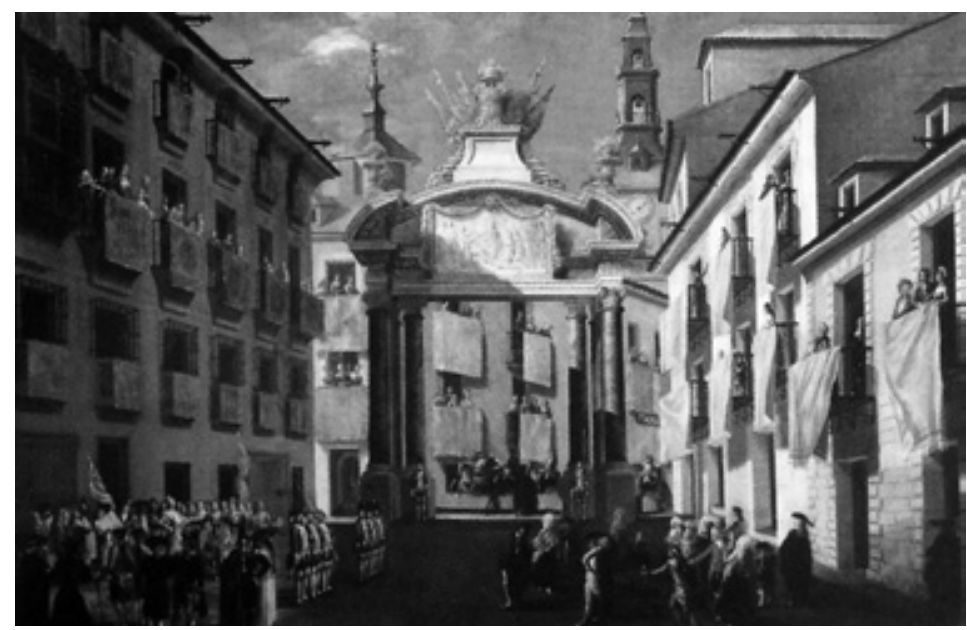

13. Lorenzo Quirós (attr.), Arco di trionfo innalzato nella calle de las Carretas in ocasione dellentrata a Madrid di Carlo III nel 1760, olio su tela, ca. 1760-1763.

(Madrid, Museo Municipal). Arquitectura de Ventura Rodríguez

virtiéndose en académico, sino la constatación de la importancia de un repertorio de ejemplos que había guiado, junto a otros tratados habituales de los siglos XVI y XVII (desde diferentes ediciones de Vitruvio a Serlio, Vignola, Palladio o Scamozzi, así como tratados franceses de Perrault a Desgodetz), el proceso de renovación de la arquitectura cortesana y española en los años anteriores, ya fuera en las obras de los Sitios Reales, especialmente en el Palacio Real Nuevo de Madrid, o en la Academia de San Fernando.

La Relación mencionada describía -mientras se preparaba una edición con estampas de los arcos levantados en honor de Carlos III, que nunca vería la luz ${ }^{69}$-, las arquitecturas, esculturas y ornamentos efímeros en los que se había querido

69 En la mencionada Relación de los arcos, inscripciones, y ornatos de la carrera por donde ha de passar el Rey Muestro Señor D. Carlos III en su entrada pública..., Madrid, Joachim Ibarra, 1760, se afirma en la "Advertencia» (p. 3) que precede a la descripción que "La estampa, y gravado de Arcos, Tropheos, y Adornos, que después se darà en la Relacion extensa, perpetuarà à los venideros lo que ahora puede cada uno vèr por sì mismo, à cuyo efecto se mantendrán los Arcos por algunos días expuestos à la vista del Público". La mencionada relación no se publicó, pero se han conservado una serie de cinco pinturas que ilustran las arquitecturas efímeras de la entrada regia de Carlos III, conservados en el Museo Municipal de Madrid, y aunque no son todos los levantados, ilustran cabalmente los modelos y lenguajes usados por Ventura Rodríguez y Felipe de Castro, herederos del barroco romano y de las estampas de las obras de los De Rossi, cuya influencia y modelos en esas obras es notoria, así como su presencia en sus respectivas bibliotecas. Véase, al respecto, con su reproducción y bibliografía anterior, Delfín Rodríguez Ruiz, "Madrid al tempo dei Rabaglio...", pp. 145-153. 
que "los Adornos, y Trophèos tuviesen preciso enlace con las Inscripciones, y estas con los heroycos hechos del Rey", añadiendo significativamente que se había pretendido también que "el estilo se formasse sobre el buen gusto Romano, por el qual se han nivelado todas las Naciones Europeas [...]. La Arquitectura de los Arcos se ha trazado sobre los monumentos que nos restan de la antigüedad, y à ella se ha ajustado el historiado de los Baxos-relieves, y Estatuas." Tanto esta descripción, como la propia imagen pintada que se ha conservado de algunos de los arcos, plantean una significativa y elocuente paradoja ya que, a la vez que se indica que las arquitecturas se han formado sobre "el buen gusto Romano" -refiriéndose al de los siglos XVI y XVII, añadiendo que ese modelo es el que más ha influido en las "Naciones Europeas", lo que confirma claramente la importancia de la circulación de estampas de la Roma antigua y moderna y su poderosa influencia en Europa y en España, especialmente las de la stamperia De Rossi-, también se añade, de manera fundamentalmente retórica, que la arquitectura, los arcos, las esculturas y bajorrelieves se han "ajustado" y "trazado sobre los monumentos que nos restan de la antigüedad", lo que no deja de ser un tópico, sobre todo en relación a las arquitecturas de Ventura Rodríguez, pendientes del barroco romano (Rainaldi, Bernini, Pietro da Cortona, Borromini, etc.) que conocía, como se ha visto, por medio de colecciones de estampas y de las obras de la stamperia De Rossi o de Carlo Fontana, cuyos Templum Vaticanum (1694) y $L^{\prime}$ Anfiteatro Flavio $(1725)^{70}$ poseía en su magnífica biblioteca. La referencia, en el texto, a la Antigüedad es un ejercicio retórico, ya que esas arquitecturas efímeras solo genéricamente fueron trazadas siguiendo modelos clásicos, como ocurría con esculturas, relieves y trofeos, en los que lo antiguo se filtraba a través de sus usos e interpretaciones durante los siglos XVI y XVII, aunque tal vez aquí la afirmación fuera más pertinente, sobre todo en relación a los temas de algunos relieves y a los trofeos y ornamentos que Felipe de Castro y Campomanes conocían sobradamente.

Precisamente un año después, en 1761, Ventura Rodríguez proyectaba el Sagrario de la Catedral de Jaén ${ }^{71}$ [14], en el que la influencia de Bernini, conocida a través de las estampas de los De Rossi, volvía a ser fundamental, como lo había sido durante los años cincuenta en tantos de sus proyectos, incluidos los no

70 Sobre Carlo Fontana véanse, entre otros, Allan Braham and Hellmut Hager, Carlo Fontana...; Hellmut Hager, Carlo Fontana. L'Anfiteatro Flavio, Edizione anastatica del manoscritto del Museo di Roma, Roma, Gangemi Editore, 2002 y Giovanna Curcio (ed.), II Tempio Vaticano 1694. Carlo Fontana, Milán, Electa, 2003.

71 Pedro Galera Andreu, "Ventura Rodríguez en Jaén», Cuadernos de Arte de la Universidad de Granada, n. ${ }^{\circ} 23,1975$, pp. 61-72. 
14. Jaén, Catedral. Interior del Sagrario, proyectado en 1761. Ventura Rodríguez

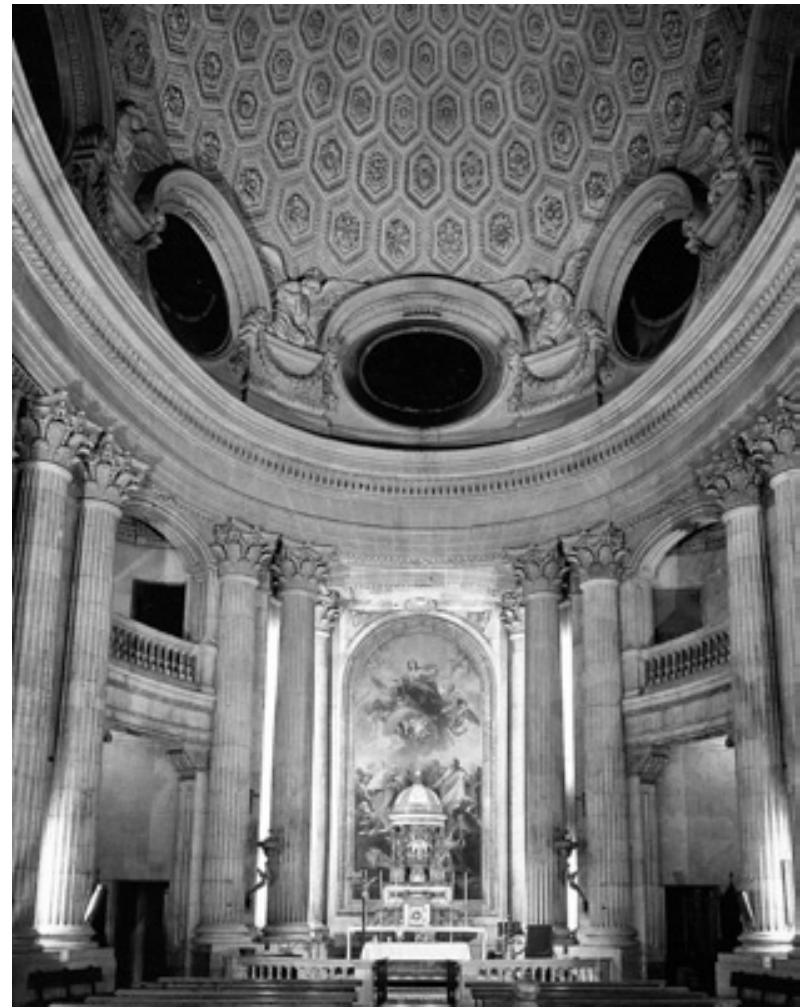

72 Delfín Rodríguez Ruiz, "Dibujos de Ventura Rodríguez...», pp. 19-130 y 127-128, respectivamente. 


\section{Q: artículos}

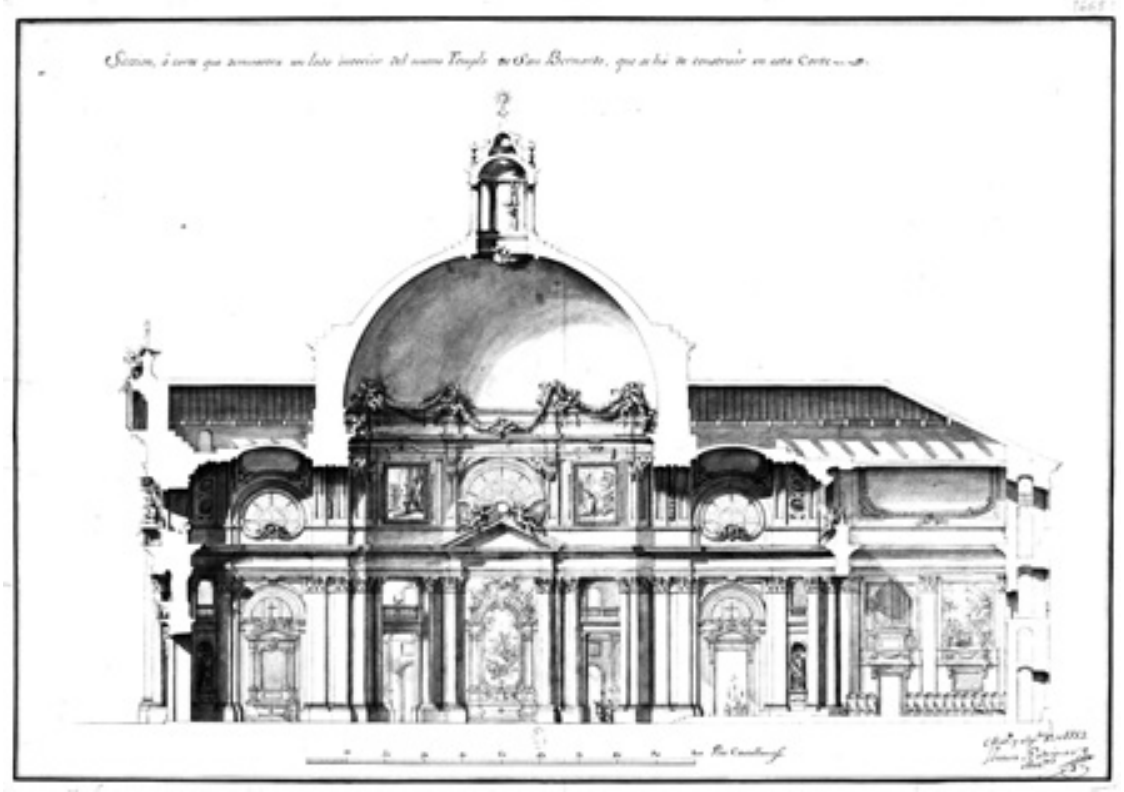

15. Ventura Rodríguez, Proyecto para el nuevo templo de San Bernardo. Sección. Dibujo a pluma, tinta y aguada gris, 1753 (Madrid, Biblioteca Nacional)

do en la cultura arquitectónica española en un recurrente elenco de soluciones ornamentales y tipológicas irrenunciables, ayudando también a establecer, ya a partir de los años cuarenta del siglo XVIII, especialmente en el ámbito de la Real Academia de Bellas Artes de San Fernando y entre sus profesores y arquitectos, un modo canónico en los sistemas mismos de representación de la arquitectura en proyección ortogonal y en la propia estructura docente de la institución.

En efecto, fue en la Academia ${ }^{73}$, en su biblioteca y en las de sus profesores primeros, donde se consolidó la presencia e influencia de los volúmenes del Studio d'Architettura Civile, que ya figuraron entre las primeras peticiones de libros en 1744, aunque no entraran en la institución hasta 1759. También en las bibliotecas de sus profesores más prestigiosos era frecuente encontrarlos, especialmen-

73 Sobre la adquisición de libros en la Real Academia de Bellas Artes de San Fernando durante sus primeros años y hasta 1793, pueden verse Claude Bédat, "La Biblioteca de la Real Academia de San Fernando en 1793", Academia, n. ${ }^{\circ} 25,1967$, pp. 5-52 y n. ${ }^{\circ}$ 26, 1968, pp. 31-86; María Luisa Tárraga Baldó, "Completo y formal inventario de cuanto D. Juan Domingo Olivieri compró para el servicio de la Academia de Bellas Artes de San Fernando", Academia, n. ${ }^{\circ} 43,1976$, pp. 7-22 y Alicia Quintana Martínez, La arquitectura y los arquitectos en la Real Academia de Bellas Artes de San Fernando (1744-1774), Madrid, Xarait ed., 1983, pp. 117-121. 
16. Ventura Rodríguez,

Proyecto para una iglesia. Sección. Dibujo a pluma, tinta y aguada gris, 1738 (Madrid, Biblioteca Nacional)

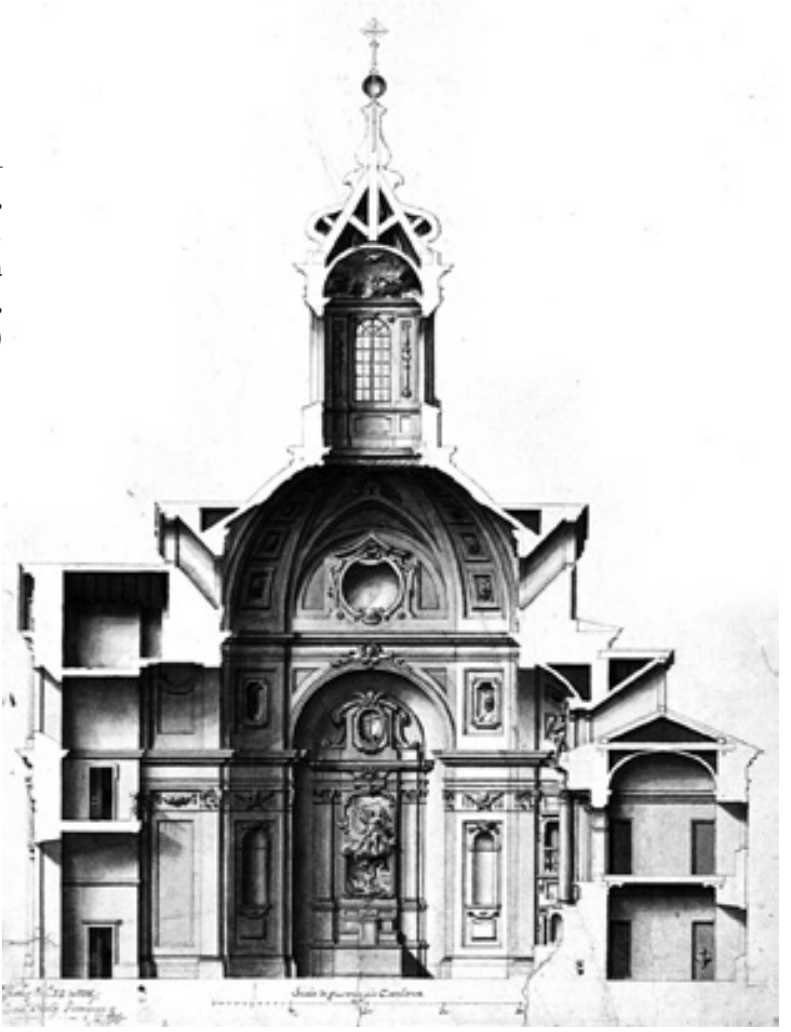

te entre los que fueron pensionados en Roma ${ }^{74}$, de Preciado de la Vega a José de Hermosilla, incluida la extraordinaria del influyente escultor Felipe de Castro ${ }^{75}$, pero también en la del escultor Juan de Villanueva y Barbales (1681-1765) ${ }^{76}$, en la que figuraba, ya en 1735, con el impreciso título de "tres libros de los templos de Rroma", lo que ha dificultado su identificación hasta ahora. Libros que pasaron después a sus hijos Diego de Villanueva (1714-1774) $)^{77}$ y Juan de Villanueva,

74 Pedro Moleón, Arquitectos españoles en la Roma del Grand Tour, 1746-1796, Madrid, Abada Editores, 2003.

75 Sobre Felipe de Castro y su biblioteca véanse los clásicos estudios de Claude Bédat, "La bibliothèque du sculpteur Felipe de Castro", Mélanges de la Casa de Velázquez, t. V, 1969, pp. 363-410 y El Escultor Felipe de Castro, Santiago de Compostela, Cuadernos de Estudios Gallegos, Anejo XX, 1971. 76 Sobre la biblioteca del padre de los Villanueva, Diego de Villanueva y Juan de Villanueva, véase ahora Bárbara García Menéndez, "La biblioteca del escultor Juan de Villanueva y Barbales (1681-1765)», BSSA arte, Universidad de Valladolid, n. ${ }^{\circ}$ LXXVI, 2010, pp. 215-240.

77 Véase ahora Bárbara García Menéndez, "Un heresiarca en la Academia. La formación de Diego de Villanueva como escultor y retablista en el entorno del Churriguerismo", Goya. Revista de Arte, n. ${ }^{\circ} 337$, 2011, pp. 312-323. 
figuras centrales en la cultura española del siglo XVIII, siendo el primero autor de algunos tratados y cuadernos de dibujos tan enormemente significativos como Colección de diferentes papeles críticos sobre todas las partes de arquitectura $(1766)^{78}$ y el segundo, pensionado en Roma, el más grande arquitecto español de la segunda mitad del Setecientos ${ }^{79}$.

Se trata de modelos, los representados en los volúmenes del Studio, que posiblemente fueron tan importantes en la renovación de la arquitectura española como la referencia misma al Monasterio de El Escorial, especialmente a partir de mediados del siglo XVIII y en el ámbito académico. Obra que, por cierto, también fue grabada por Domenico de Rossi. En efecto, es significativo y nunca, que yo conozca, ha sido mencionado ni reproducido hasta ahora, ni entre los estudiosos de El Escorial ni tampoco entre los de la Regola (1562) de Vignola, que el propio Domenico de Rossi, en una de sus primeras obras como heredero de la stamperia de Giovanni Giacomo, incluyese cuatro estampas dedicadas al monasterio de Felipe II en su rara edición de la Regola delli cinque Ordini d'Architettura di M. lacomo Barozzio da Vignola. In Roma nella Stamperia di Domenico de Rossi alla Pace con Priuilegio (1699?) ${ }^{80}$, lo que merecería, sin duda, un estudio más detenido. Las cuatro estampas, numeradas de la 55 a la 58 [17 a y b], son reelaboraciones enormemente interesantes de las contenidas en la importantísima obra de Juan de Herrera, grabada por Pierre Perret, de las estampas y el Sumario y Breve declaración de los diseños y estampas de la Fábrica de San Lorenzo el Real del Escorial (1589) ${ }^{81}$.

78 Diego de Villanueva, Colección de diferentes papeles críticos sobre todas las partes de arquitectura (Valencia, Benito Monfort, 1766), Madrid, Real Academia de Bellas Artes de San Fernando, 1979, con estudio introductoria de Luis Moya, pp. 9-39 y, entre otros, Diego de Villanueva, Libro de diferentes pensamientos unos inventados y otros delineados por Diego de Villanueva. Año de 1754, Madrid, Real Academia de Bellas Artes de San Fernando, 1979, edición al cuidado de Thomas F. Reese.

79 Sobre Juan de Villanueva la bibliografía es enorme, pero véanse Fernando Chueca Goitia y Carlos de Miguel, La vida y las obras de Juan de Villanueva... y Pedro Moleón, Juan de Villanueva, Madrid, Ed. Akal, 1998.

80 Véase la mención de esta edición de Vignola por Domenico de Rossi en Anna Grelle lusco (ed.), Indice delle Stampe..., p. 324.

81 Sobre esta obra de Juan de Herrera y las estampas de El Escorial la bibliografía es enorme, pero véanse los trabajos clásicos de Luis Cervera Vera, Las Estampas y el Sumario de El Escorial por Juan de Herrera ( $1^{a}$ ed., 1954), Madrid, Colegio Oficial de Arquitectos de Madrid, 1998 y Elena Santiago Páez (ed.), El Escorial en la Biblioteca Nacional, Madrid, Biblioteca Nacional, 1985, pp. 230-253. En relación al monasterio de El Escorial y a su influencia en la arquitectura española durante los reinados de los primeros Borbones en la Monarquía Hispánica pueden verse Fernando Marías, "El Escorial entre dos Academias: juicios y dibujos", Reales Sitios, n. ${ }^{\circ} 149,2001$, pp. 2-19 y Delfín Rodríguez Ruiz, "La sombra de un edificio. El Escorial en la cultura arquitectónica española durante los primeros Borbones (17001770)", Quintana. Revista do departamento de Historia da Arte, Universidad de Santiago de Compostela, n. ${ }^{\circ} 2,2003$, pp. 57-94. 

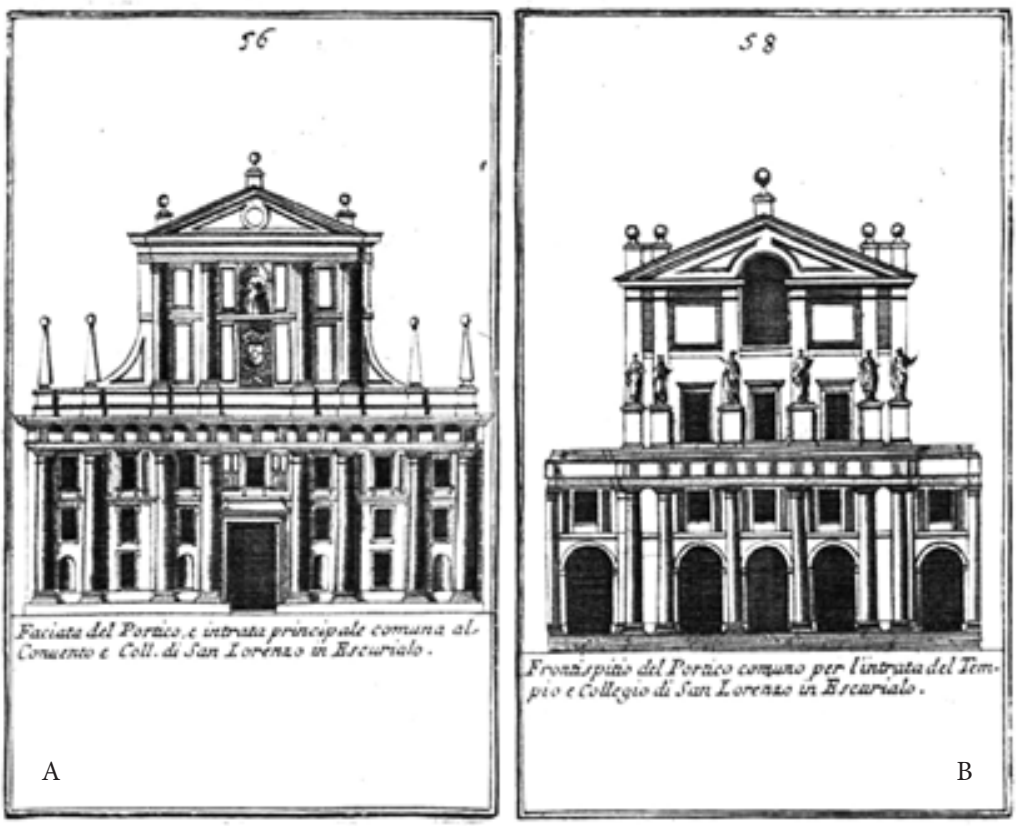

17. A) Domenico de Rossi, Facciata del Portico, e intrata principale comuna al Convento, Coll. di San Lorenzo in Escurialo, in Regola delli cinque Ordini d'Architettura di M. Iacomo

Barozzio da Vignola...Roma, 1699? Lám. 56. B) Îdem, Lám. 58: Frontispitio del portico comuno per l'intrata del Tempio e Collegio di San Lorenzo in Escurialo

Por otra parte, en este contexto, un arquitecto e ingeniero militar tan significativo en la arquitectura española de los años centrales de siglo XVIII como José de Hermosilla y Sandoval (1715-1776) poseyó también en su interesantísima biblioteca, recientemente conocida pero aún sin estudiar ${ }^{82}$ adecuadamente, los tres ejemplares del Studio dell'Architettura Civile de Domenico de Rossi. En el inventario de la misma, de 1776, figuran como "Arquitectura Civil en Tres tomos»

82 La biblioteca de José de Hermosilla se encuentra en el inventario de sus bienes conservado en AGMS (Archivo General Militar de Segovia), 9a/ Caja 1802. Exp. 14438. Ha sido dada a conocer por Martine Galland Seguela, Les ingénieurs militaires espagnols de 1700 à 1803, Madrid, Casa de Velázquez, 2008, pp. 172 y 316 . Vinculada a esa publicación puede consultarse, en el site internet de la Casa de Velázquez (Madrid), el Fichier prosopographique con listados de las bibliotecas de los ingenieros militares, incluida la de Hermosilla, aunque con numerosas inexactitudes con respecto a la documentación de su inventario conservado en AGMS y ya citado. De hecho, no menciona precisamente los tres volúmenes de la obra de Domenico de Rossi, Studio dell'Architettura Civile que, según ese documento, Hermosilla poseía. Véase también Marie-Hélène García, La culture des ingénieurs militaires en Espagne au siècle des Lumières (XVIIle siècle-début du XIXe siècle), Tesis de doctorado, Burdeos, 2004. No he podido consultar su memoria de DEA (Burdeos, 1999) titulada Les bibliothèques de militaires espagnols au $X V I I l e$ siècle, en la que se detiene especialmente en la biblioteca de Hermosilla. 
y no han sido advertidos ni identificados por los estudiosos que recientemente se han referido a su biblioteca. Comprados muy posiblemente durante su estancia en Roma, entre 1747 y 1751, como pensionado de arquitectura por la Junta Preparatoria de la que habría de ser, a partir de 1752, Real Academia de Bellas Artes de San Fernando de Madrid, contribuyeron, sin duda, a fijar en su memoria de arquitecto la Roma moderna que dibujó (Palacio de los Conservadores en el Capitolio o Sant'Andrea al Quirinale) y contempló en aquellos años y que acabaría sirviendo de modelo para muchas de sus soluciones y, sobre todo, para establecer y asumir conscientemente el recorrido histórico de la arquitectura del Renacimiento a los grandes maestros del barroco romano, convirtiéndolos así en una referencia ineludible en la arquitectura española de la época y punto de partida para su renovación institucional y académica, cosmopolita y cortesana. Entre los dibujos que envió a la Academia desde Roma, su proyecto para un Templo (1748) [18 a y b] muestra la habilidad en componer un edificio que no solo atiende a lo visto, sino también a lo publicado en estampas ( $y$, en ocasiones, no construido) por Domenico de Rossi en su Studio. Así, en ese proyecto se articulan modelos como Santa Agnese in Piazza Navona con ejercicios académicos habituales en la Accademia di San Luca y, en la fachada, con la memoria del proyecto, no realizado, de Bernini para el ábside de

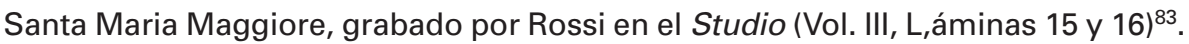

Si su tratado de Architectura Civil, conservado manuscrito en dos copias diferentes y elaborado en Roma, en $1750^{84}$, es un testimonio de primer orden de los debates, novedades y tradiciones que estaban activas en esa época en la ciudad, aunque su intención fuera la de proporcionar una especie de manual para la academia madrileña -que a la postre quedaría inédito-, también constituye un instrumento privilegiado para conocer su cultura en ese período y deducir los tratados que pudo manejar en Roma, con independencia de los que había utilizado en su primera formación en España y en la obras del Palacio Real Nuevo de Madrid, en el que colaboró como delineante con Ventura Rodríguez y Diego de Villanueva, entre otros, a las órdenes de Giovanni Battista Sacchetti.

Precisamente en su biblioteca se encontraban los dos ejemplares de su tratado de Architectura Civil que son conocidos, figurando como "Dos tomos

83 Delfín Rodríguez Ruiz, "Arquitectura y Academia...», pp. 2286236.

84 El tratado de Architectura Civil (1750) de José de Hermosilla, conservado en la Biblioteca Nacional de Madrid, pude darlo a conocer en Delfín Rodríguez Ruiz, "De la utopía a la Academia. El tratado de Architectura Civil de José de Hermosilla", Fragmentos. Revista de Arte, n. ${ }^{\circ} 3,1985$, pp. 57-80. Otra copia del tratado, conservado en la biblioteca de la Academia de Buenas Letras de Sevilla pude también darlo a conocer en Delfín Rodríguez Ruiz, La memoria frágil. José de Hermosilla y las Antigüedades árabes de España, Madrid, Fundación COAM, 1992, pp. 22-24. De próxima publicación, he preparado una edición crítica del tratado, acompañado de una monografía sobre su actividad como arquitecto e ingeniero. 
18. A) José de Hermosilla, Proyecto de templo. Alzado de la fachada. Dibujo a pluma, tinta y aguadas grises y marrones, 1748 (Madrid, Real Academia de Bellas Artes de San Fernando). B) Domenico de Rossi, Studio d'Architettura Civile, III (1721), Lám. 15: Facciata della Tribuna della Basilica di Santa Maria Maggiore secondo il disegno del Cav re Bernini non posto in opera
A
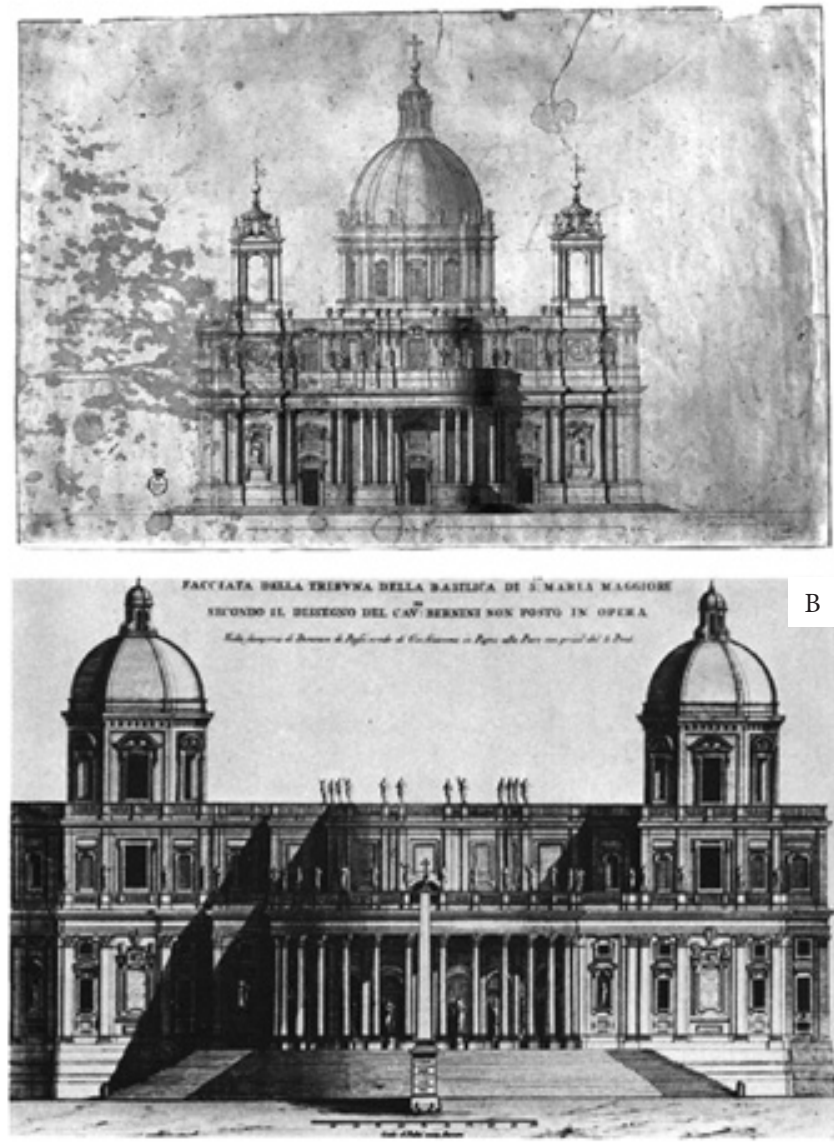

Manuscriptos Arquitectura cibil por el referido Don Josef de Ermosilla». Sus relaciones en Roma debieron de ser extraordinariamente estimulantes, como se desprende de las presentaciones de su propio tratado manuscrito, realizadas por Ferdinando Fuga, Fray Alonso Cano y Nieto, Ruggero Boscovich y François Jacquier. Con el primero colaboró en el levantamiento de planos del palacio de la Embajada de España en Roma ${ }^{85}$ y con el segundo en la terminación y ornamentación interior de la iglesia de los Trinitarios Calzados en via Condotti ${ }^{86}$,

85 Véase ahora Mercedes Simal, «El palacio de España en Roma a través de los dibujos de Ferdinando Fuga y José de Hermosilla", Archivo Español de Arte, n. ${ }^{\circ} 321,2008$, pp. 31-48.

86 La intervención de Hermosilla en la iglesia de los Trinitarios de via Condotti, bajo la supervisión de Fray Alonso Cano, que no solo presentó su tratado manuscrito, sino que tuvo con él una relación muy estrecha, aún no está clarificada. Véase, con la bibliografía anterior, el reciente estudio de Alessandra 
además de conocer el ambiente en el que Giambattista Nolli realizó su célebre y extraordinaria obra de la Nuova Pianta di Roma (1748) ${ }^{87}$, que Hermosilla poseía también y que le sirvió de modelo para la realización del Plano topográfico de la villa y corte de Madrid, grabado, en 1769, por Antonio Espinosa de los Monteros, grabador con el que coincidió en Roma entre 1750 y $1751^{88}$, y dedicado al Conde de Aranda, su protector, a su regreso a España, tanto en la Academia de Madrid, como en el Cuerpo de Ingenieros Militares, al que se incorporó en 1756.

La importancia que el repertorio del Studio d'Architettura Civile tuvo en su tratado fue ciertamente significativa, aunque préstamos directos en las láminas que ilustran la Achitectura Civil de nuestro arquitecto no son fácilmente identificables, si se exceptúa su modelo de escalera de forma circular (Lámina en pág, 238) [19], dibujada en planta y sección y que parece sacada de la estampa de la escalera del Palazzo Farnese di Caprarola (Studio, T. III, tav. 68). Es verdad que no cita la obra publicada por Domenico de Rossi, pero debió de tenerla presente mientras escribía su tratado y dibujaba las láminas del mismo, lo que explicaría el carácter romano de buena parte de su lenguaje ornamental en ventanas, puertas y algunas plantas de edificios, sobre todo en el caso de los religiosos, como ocurre con la capilla de su modelo de convento (Lámina en pág. 269) [20 a y b], que está inspirada genéricamente en la planta de Santa Agnese in Piazza Navona, posiblemente tomada no del Studio, en el que, como es sabido, no se encuentra la planta completa, sino del Insignium Romae Templorum $(1684)^{89}$, de

Anselmi, "La chiesa della Santísima Trinità degli Spagnoli», en Carlos José Hernando (ed.), Roma y España. Un crisol de la cultura europea de la Edad Moderna, Madrid, SEACEX, 2007, vol. 2, pp. 915-930. Las iniciativas arquitectónicas de Fray Alonso Cano (1711-1780) durante su estancia en Roma, entre 1747 y 1752, fueron notables, especialmente en el caso de la terminación de la iglesia de los Trinitarios Calzados en via Condotti, cuyas obras y diseño de los altares encargó a José de Hermosilla, con el que coincidió casi en los mismos años de su estancia en la ciudad. La pasión del religioso trinitario por la arquitectura continuó a su vuelta a España, promoviendo diferentes e importantes obras, sobre todo como obispo, a partir de 1770, en la diócesis de Segorbe (Castellón), incluida la reforma neoclásica de su catedral, siguiendo un proyecto del arquitecto Vicente Gascó. Precisamente, en la mencionada catedral se conserva un interesantísimo retrato anónimo del obispo en el que Fray Alonso Cano aparece acompañado por un fragmento de la planta de la iglesia de la Trinità in via Condotti, señal inequívoca del aprecio que debía tener a aquella obra y al recuerdo de sus años romanos. Al respecto, véase Joaquín Bérchez, La renovación ilustrada de la catedral de Segorbe. Del obispo Alonso Cano al arquitecto Vicente Gascó, Valencia, 2001, con el retrato reproducido en la pág. 5.

87 Sobre el ambiente científico y arquitectónico de la Roma de Nolli, con el que tuvo relación HermosiIla, véase Mario Bevilacqua, Roma nel secolo dei Lumi. Architettura, erudizione, scienza nella pianta di G. B. Nolli "celebre geometra», Nápoles, Electa Napoli, 1998.

88 Sobre la relación entre Espinosa de los Monteros y Hermosilla en Roma y en el Plano de Madrid, de 1769, véase Delfín Rodríguez Ruiz, "José de Hermosilla y Sandoval, Plano de los paseos del Prado, Recoletos y Atocha de Madrid, 1767", en Isabel García Toraño (ed.), Dibujos de Arquitectura y Ornamentación de la Biblioteca Nacional. Tomo II. Siglo XVIII, Madrid, Biblioteca Nacional, 2008, pp. 46-48.

89 Una edición reciente, con estudio introductori0 de José Manuel Barbeito, "Giovanni Giacomo de Rossi. El poder de la estampa», puede verse en Givanni Giacomo de Rossi, Insignium Romae Templorum (1684), Madrid, Instituto Juan de Herrera-Escuela Técnica Superior de Arquitectura de Madrid, 


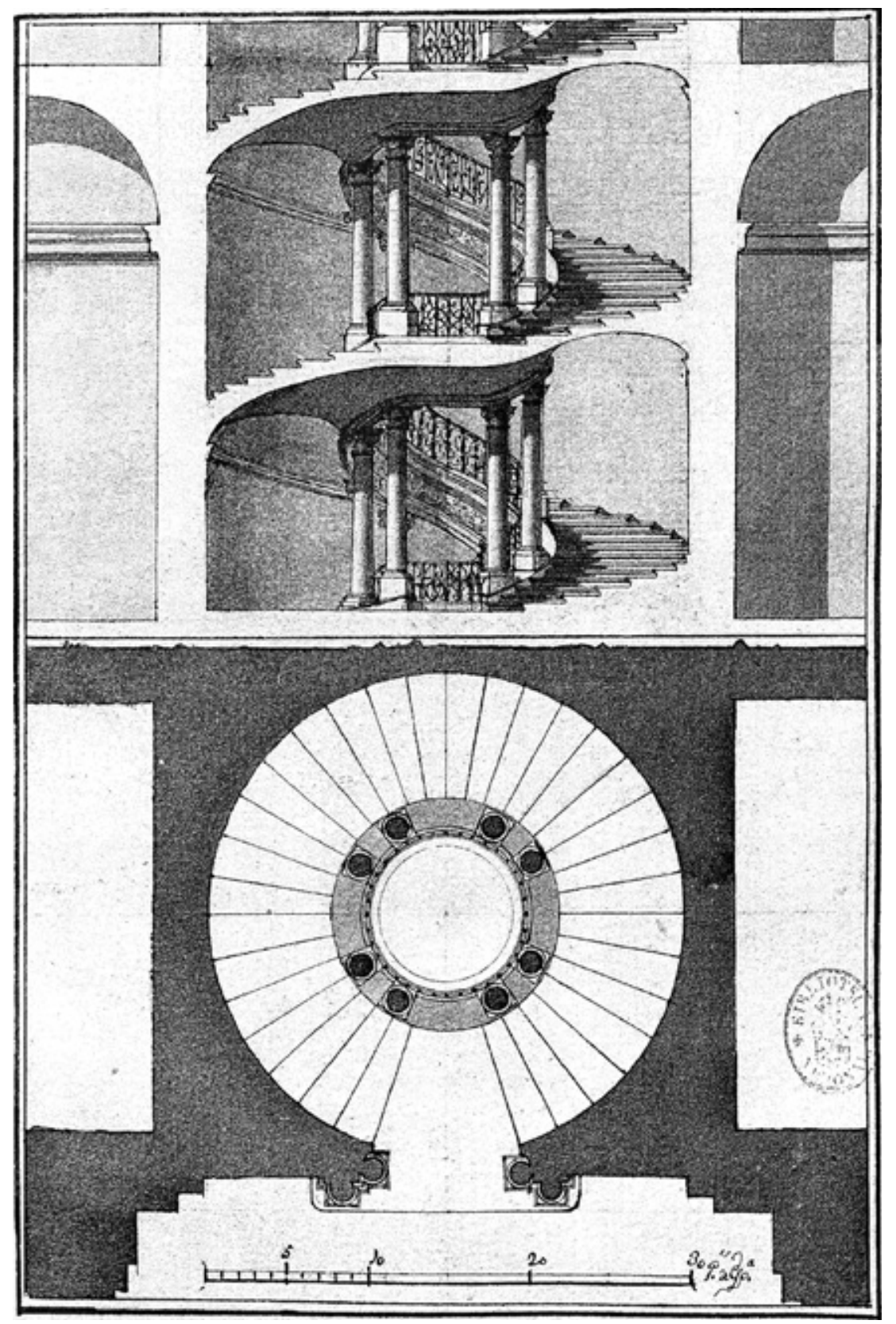

19. José de Hermosilla, Escalera de planta circular. Dibujo a pluma, tinta y aguadas grises, 1750, en su Tratado de Architectura Civil, manuscrito y fechado en Roma en 1750, p. 283 (Madrid, Biblioteca Nacional) 

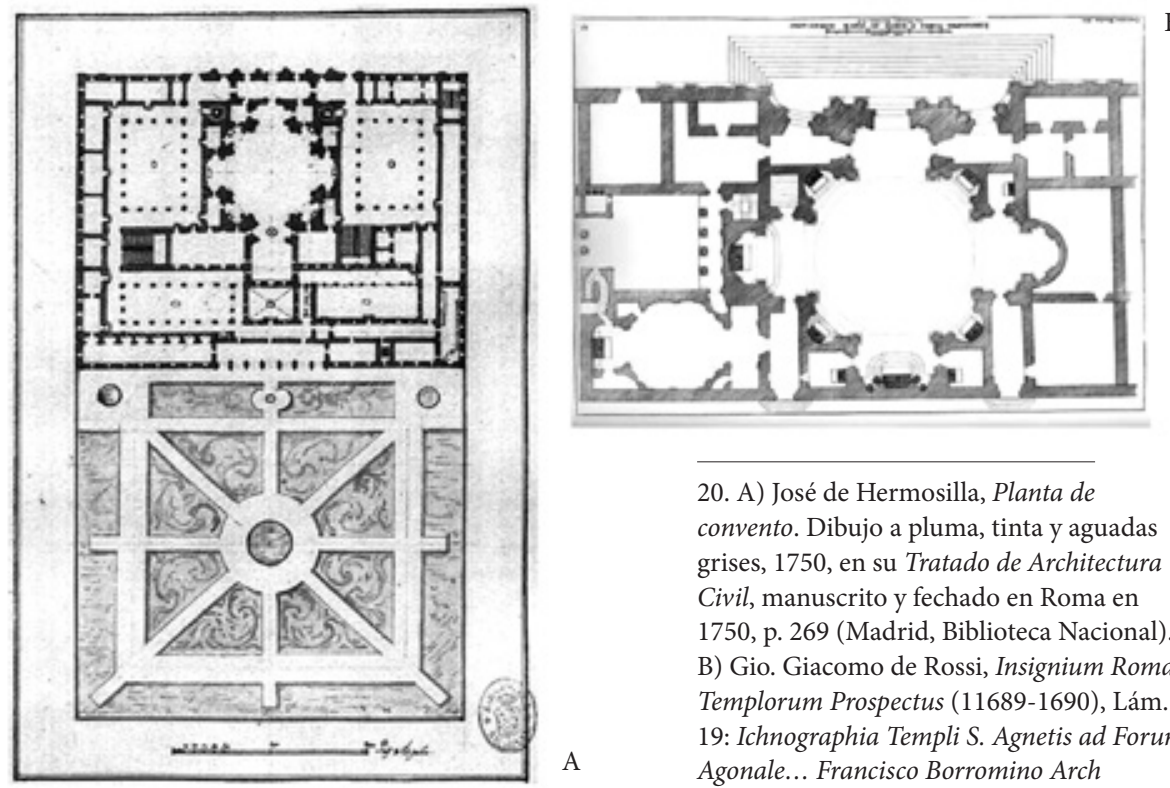

20. A) José de Hermosilla, Planta de convento. Dibujo a pluma, tinta y aguadas grises, 1750, en su Tratado de Architectura Civil, manuscrito y fechado en Roma en 1750, p. 269 (Madrid, Biblioteca Nacional). B) Gio. Giacomo de Rossi, Insignium Romae Templorum Prospectus (11689-1690), Lám. 19: Ichnographia Templi S. Agnetis ad Forum Agonale... Francisco Borromino Arch

Giovanni Giacomo de Rossi, obra que, sin duda debía de conocer, incluso antes de su estancia en Roma, ya que figuraba en varias bibliotecas de arquitectos españoles e italianos que trabajaron en España con anterioridad a su partida en 1747 y, especialmente, en ámbitos cortesanos.

Sea como fuere, se trata de dos obras de la stamperia De Rossi (el Insignium de Giovanni Giacomo de Rossi y los tres volúmenes del Studio de Domenico de Rossi) que Hermosilla conocía, así como seguramente el tratado muy difundido en España, casi más que las dos obras anteriores, de Giovanni Giacomo de Rossi, Disegni di Vari Altari e Cappelle nelle Chiese di Roma (1689-1691?) ${ }^{90}$. Obra de la que el propio arquitecto, en un proyecto tardío (1770) como fue su retablo para iglesia parroquial de Irurita ${ }^{91}$, en Navarra, se hace eco, de un modo tal vez anacrónico ya en esa época, incluso en la arquitectura española.

2004. Sobre la representación de la arquitectura en esa obra véase Francisco Martínez Mindeguía, "Insignium Romae Templorum Prospectus, la visión frontal de la arquitectura", Annali di Architettura, n. ${ }^{\circ}$ 17, 2005, pp. 167-182.

90 Sobre las fechas de edición de Disegni di Vari Altari e Capelle véanse Anna Grelle lusco (ed.), Indice delle Stampe intagliate in rame a bulino, e in acqua forte esistenti nella Stamperia di Lorenzo Filippo de' Rossi. Contributo alla storia di una estamperia romana..., pp. 52 y 400 y Simona Ciofetta, "Alcune edizioni di architettura di Gian Giacomo e Domenico de Rossi: fasi preparatorie e finalità dell'opera", en Studi su Settecento romano, n. ${ }^{\circ} 13,1997$, pp. 65-73.

91 Sobre el retablo de Irurita y su atribución a Hermosilla véase María Teresa Cruz Yábar, "José de Hermosilla y el retablo de Irurita en Navarra", Archivo Español de Arte, n. ${ }^{\circ}$ 290, 2000, pp. 147-162. 
En cualquier caso, a partir de mediados del Setecientos, el Studio de Domenico de Rossi, así como otras muchas obras de la stamperia alla Pace, era moneda corriente en bibliotecas de arquitectos y entre ingenieros militares que, como el ya recordado Verboom o Hermosilla, lo poseyeron y utilizaron, de Pedro Martín Cermeño (1722-1790) ${ }^{92}$ a Francisco Sabatini (1721-1797) ${ }^{93}$, figuras fundamentales también en la arquitectura española de la segunda mitad del siglo XVIII.

Conocido entre los profesores de la Academia de San Fernando, no fue hasta 1759 cuando los dos primeros volúmenes del Studio d'Architettura Civile (1702 y 1711) entraron a formar parte de la biblioteca de la institución, aunque no el tercero, que nunca lo haría ${ }^{94}$. Precisamente fue en enero de ese año cuando José de Castañeda, que estaba enfrascado tanto en la redacción del nunca realizado Curso de Arquitectura para la Academia, en compañía de Diego de Villanueva, así como preparando la edición castellana del Compendio de Vitruvio de Perrault, publicado en $1761^{95}$, hizo la propuesta para la compra de los volúmenes del Studio de Domenico de Rossi, añadiendo a su lista de peticiones a la Junta Particular de la Academia los tratados de Tosca, Compendio Matemático $\left(3^{\mathrm{a}}\right.$ ed., 1757), Wolf, Cours de Mathématiques (1747), Belidor, La science des ingénieurs (1729), Desgodetz, Les édifices antiques de Rome (1682), Roland Fréart de Chambray, Parallèle de l'architecture antique et de la moderne (1702), entre otros. Se trata de los dos volúmenes que hoy se conservan en la biblioteca de la Academia y resulta su elección particularmente interesante ya que los pedía precisamente para la redacción del Curso de Arquitectura nunca publicado, como tampoco lo fue el de Hermosilla de 1750, y que debía someterse al paradójico dictamen de la institución de que debía tratarse de un compendio de los mejores autores conocidos. Del mencionado proyecto se conservan el texto manuscrito y los dibujos del tratado de Geometría para el citado Curso, así como algunas estampas grabadas y un único ejemplar conocido e impreso de la parte que debía hacer Diego de Villanueva. Si en ese proyecto, lo francés fue hegemónico, no deja de

92 Sobre la biblioteca de Cermeño véase Martine Galland Seguela, Les ingénieurs militaires... Y el site internet correspondiente de la Casa de Velázquez (Madrid), así como Alfredo Vigo Trasancos, «El capitán general Pedro Martín cermeño (1779-1790) y el Reino de Galicia. Poder, arquitectura y ciudad", Semata. Ciencias Socials e Humanidades, vol. 10, 1998, pp. 171-202.

93 La extraordinaria biblioteca de Francisco Sabatini, discípulo de Luigi Vanvitelli, formado en Roma en los mismos años que Hermosilla y fundamental arquitecto de Carlos III en España, puede verse, con numerosos libros de la stamperia de los Rossi, incluido el Studio d'Architettura Civile, en Antonio Ruiz Hernando, "La testamentaría de Francisco Sabatini», en Delfín Rodríguez Ruiz (ed.), Francisco Sabatini (1721-1797). La arquitectura como metáfora del poder, Madrid, Electa, 1993, pp. 91-114.

94 Claude Bédat, "La Biblioteca de la Real Academia...", n. ${ }^{\circ} 26,1986$, p. 60 (n. ${ }^{\circ} 860$ ).

95 José de Castañeda, Compendio de los Diez Libros de Arquitectura de Vitruvio. Escrito en Francés por Claudio Perrault, (Madrid, Gabriel Ramírez, 1761), Murcia, Colegio Oficial de Aparejadores y Arquitectos Técnicos, 1981, con Estudio Introductorio de Joaquín Bérchez, pp. IX-XCIV. 
resultar especialmente significativo que, de la arquitectura romana, Castañeda solicitase la compra del volumen de Desgodetz, dedicado a la Roma antigua y cuyas estampas gozarían de una enorme fortuna en los ejercicios académicos de los estudiantes ${ }^{96}$, como puede comprobarse en los dibujos conservados, mientras que eligió, para la Roma moderna, los volúmenes del Studio de Domenico de Rossi, máxime tratándose de un arquitecto que se había formando en París, frecuentando la Academia de Arquitectura privada de Jacques-François Blondel a mediados de los años cincuenta ${ }^{97}$.

Libro fundamentalmente pensado para arquitectos, también entre los tratadistas vinculados a la Academia de Bellas Artes de San Fernando fueron varios los que tuvieron presente el Studio d'Architetura Civile de Domenico de Rossi, así como el Insiginium o Disegni di Vari Altari de Giovanni Giacomo de Rossi $y$, entre ellos, el primero aparece mencionado en el muy influyente tratado del jesuita Christian Rieger, Elementos de toda la Architectura Civil, publicado originalmente en Viena, en 1756, y traducido y ampliado, con variantes significativas en algunas ilustraciones, por el también jesuita Miguel Benavente, en 1763, profesores los dos, por entonces, en el Colegio Imperial de Madrid. El tratado se convirtió, durante los años sesenta y setenta del siglo XVIII, casi en el manual de arquitectura ${ }^{98}$ que la Academia de San Fernando y sus profesores de arquitectura no habían podido publicar. Sirvió, por la variedad de sus fuentes y por sus ilustraciones, no solo para difundir los tratados más convencionales y conocidos de arquitectura (italianos, franceses, británicos y alemanes), sino que también introdujo una especie de debate o estado de la cuestión confrontando, frente a la tradición vitruviana y académica -incluidos los modelos del Gesù de Roma y el Palacio de Caserta, de Vanvitelli, que reproduce-, las ideas de Cordemoy y de Laugier, aunque fuera para discutirlas, así como los fascinantes modelos históricos y Maravillas del Mundo de Johann Bernard Fischer von Erlach contenidos en su Entwurf einer historischen Architektur (Viena, 1721), reproduciendo de manera diminuta, en forma de "florones» al comienzo y al final de sus capí-

96 Delfín Rodríguez Ruiz, "Imágenes de lo posible: los proyectos de arquitectura premiados por la Real Academia de Bellas Artes de San Fernado (1753-1831), en Hacia una nueva idea de la arquitectura. Premios Generales de Arquitectura de la Real Academia de Bellas Artes de San Fernando (1753-1831), Madrid, Real Academia de Bellas Artes de San Fernando, 1992, pp. 13-31.

97 Sobre José de Castañeda y su formación francesa y la edición del Compendio de Vitruvio, de Perrault (Madrid, 1761), véase Delfín Rodríguez Ruiz, "La sombra de un edificio. El Escorial en la cultura arquitectónica...", pp. 77-79.

98 Sobre el tratado de Rieger y sus fuentes y significado en la arquitectura española del momento véase Delfín Rodríguez Ruiz, José Ortiz y Sanz. Teoría y crítica de la arquitectura, 2 vols., Madrid, Colegio Oficial de Arquitectos de Madrid, 1991, vol. I, pp. 86-94. Ortiz y Sanz también usó en sus ediciones, traducciones y obras manuscritas de arquitectura del repertorio de Domenico de Rossi. 
tulos, muchas de las estampas del tratado del arquitecto austríaco, difundiendo así en España una obra fundamental del imaginario arquitectónico europeo y que debieron o pudieron usar Andrea Procaccini en la Colegiata del Palacio de La Granja, Diego de Villanueva en la ilustración imaginaria de la antigua Cartago para una obra de Campomanes (1754) $)^{99}$ o el mismo Ventura Rodríguez en su proyecto para la fachada de la Iglesia de San Norberto en Madrid (1757), así como también fue recomendado por José Ortiz y Sanz, el editor de Vitruvio (1787) y Palladio (1797) ya a finales del siglo XVIII. Pues bien, en el rico capítulo final con un índice de los escritores de arquitectura, completado por el padre Benavente, se incluye el Studio Architettura de Rossi con el siguiente enunciado, un tanto lacónico: "DOMINGO DE ROSSI publicó un Tratado, con título: Studium Architecturae Civilis, de los ornamentos de las puertas, y ventanas ${ }^{100}$. Descripción que no deja de ser injusta en relación a la enorme complejidad del repertorio de estampas que contiene, pero que ilustra un posible uso e idea que del mismo podía tenerse en determinados sectores de la Academia de San Fernando, no propio de arquitectos, sino de teóricos y aficionados cultos.

En todo caso, en los tratados y en los libros de viajes que describen España no es infrecuente, durante los años setenta y ochenta del siglo XVIII, encontrar referencias a los repertorios de láminas de la arquitectura de la Roma moderna, fundamentalmente a las editadas por la stamperia de Rossi, del Insignium a los volúmenes del Studio, aunque, a menudo, a partir de esas fechas, las menciones son más históricas y culturales, que disciplinarmente arquitectónicas, lo que, sin embargo, había sido lo habitual en los decenios anteriores. Es decir, casi como dando la razón al mismo Domenico de Rossi que en la presentación al lector (Agli Amatori delle Belle Arti), en el primer volumen del Studio (1702), ya había previsto ese doble uso de su proyecto editorial. Así, en primer lugar, planteaba que esas estampas debían contribuir tanto a la propaganda de la magnificencia de príncipes y ciudades, de mecenas y arquitectos, como a conservar la memoria de los edificios frente al tiempo ${ }^{101}$ devorador y a la inevitable ruina, sin olvidar, en segundo lugar, que habían sido pensadas y realizadas por el "peritissimo»

99 Delfín Rodríguez Ruiz, "Madrid al tempo dei Rabaglio...", p. 149.

100 Christiano Rieger, Elementos de toda la Architectura Civil... los quales, aumentados por el mismo, da traducidos al castellano el P. Miguel Benavente, Madrid, Joachin Ibarra, 1763, p. 308.

101 En la mencionada dedicatoria a los Amatori delle Belle Arti, Domenico Rossi escribe que el sentido de sus estampas sobre Roma fue el de "eternare al possibile sù le Carte que' medesimi marmi, quelli edifizii, e quelle opere, alle quali non sà perdonare la voracità, e l'inguria del tempo", en Domenico de Rossi, Studio d'Architettura Civie sopra gli Ornamenti di Porte e Finestre, tratti da alcune Fabbriche insigni di Roma..., Roma alla Pace, 1702. Parte Prima, p. 3. 
Alessandro Specchi para ayudar al "moderno architetto" ${ }^{102}$ en sus proyectos. Es decir, que una vez que históricamente esa ayuda a los arquitectos comenzaba a ser propia del pasado y ofrecía modelos desusados, incluso anacrónicos, siempre quedaba la función primera de testimonios de la grandeza de un príncipe o de una ciudad, de la historia de la arquitectura y su memoria antes de que, en este caso, sobre la Roma moderna pudiese afirmarse aquello que fue tópico sobre la antigua: Roma quanta fuit ipsa ruina docet ${ }^{103}$.

Es en ese sentido en el que en otros muchos tratados españoles y viajes descriptivos de fechas más tardías, a partir de los años setenta del Setecientos, puede comprobarse el uso ya casi exclusivamente cultural e histórico de las arquitecturas de Roma representadas en sus estampas, previsto por el propio Domenico de Rossi, y ya no necesariamente proyectual o arquitectónico, útil al que pudiera haber sido "moderno architetto" entre 1702 y mediados de siglo. Así, mientras en la arquitectura construida, en los proyectos académicos o en dibujos, las estampas del Studio fueron casi abandonadas, no ocurrió lo mismo en el caso de tratados teóricos de arquitectura como el muy interesante del Marqués de Ureña (Reflexiones sobre la arquitectura, ornato y música del Templo, 1785), que usó y citó los edificios de la Roma moderna ilustrados en el Studio y en el Insignium en un contexto más propio de la crítica arquitectónica que de la idea del proyecto, aunque se base en ellos como argumentos de autoridad ${ }^{104}$. Un uso que sería continuado por el erudito José Ortiz y Sanz (1739-1822), traductor de Vitruvio y Palladio, como se ha visto.

También en su imprescindible y todavía utilísimo Viage de España (17721794), Antonio Ponz (1725-1792) ${ }^{105}$, viajero a Roma, permaneciendo, como pintor, en la ciudad y en Nápoles entre 1751 y 1761 -aunque la mayor parte de su estancia parece que la dedicó al estudio de las artes y la arquitectura-, usó de las obras de Giovanni Giacomo y Domenico de Rossi, de quien cita precisamente los tres volúmenes del Studio ${ }^{106}$, recomendándolos, entre un rico elenco de tratados

\footnotetext{
102 Ibid.

103 Véase, al respecto, con la bibliografía anterior sobre este apasionante asunto, Delfín Rodríguez Ruiz, "De arquitectura y ciudades pintadas. Metáforas del tiempo, del espacio y del viaje», en Delfín Rodríguez Ruiz y Mar Borobia (eds.), Arquitecturas Pintadas. Del Renacimiento al Siglo XVIII, Madrid, Museo Thyssen-Bornemisza, 2001, pp. 19-49.

104 Marqués de Ureña, Reflexiones sobre la Arquitectura, Ornato y Música del Templo, Madrid, Joachin Ibarra, 1785, pp. 220-223.

105 Véase, ahora, Daniel Crespo Delgado, Un viaje para la llustración. El Viaje de España (1772-1794) de Antonio Ponz, Madrid, Marcial Pons, 2012.

106 La mención al Studio de Domenico de Rossi se encuentra en el volumen VII del Viage de España, Madrid, Joachin Ibarra, 1784. Cito por la edición, al cuidado de Casto María del Rivero, Antonio Ponz, Viaje de España, 4 vols., Madrid, Aguilar, 1988, vol. 2, p. 358.
} 
y colecciones de estampas -muchos de ellos ya mencionados más arriba-, para la formación histórica de los jóvenes estudiantes de arquitectura de la Academia de Bellas Artes de San Fernando, de la que sería secretario a partir de 1776.

\section{Coda sobre algunos dibujos conservados en España y relacionados con el Studio d'Architettura Civile de Domenico de Rossi}

Aunque no cabe duda de que un seguimiento más detenido podría ayudar a localizar en España algunos dibujos más que pudieran tener una relación directa o indirecta con el proyecto editorial y con las propias estampas del Studio d'Architettura Civile de Domenico de Rossi, lo cierto es que solo unos cuantos, conservados en la Biblioteca Nacional de España en Madrid, pueden vincularse con las mencionadas láminas. Y esto con independencia de otros muchos dibujos y proyectos de arquitectos españoles e italianos -a algunos de los cuales ya se ha hecho referencia- que pudieran haberse servido de ese repertorio para formular otras propuestas o resolver proyectos autónomos. Resulta revelador también que entre los dibujos conservados de los estudiantes de arquitectura de la Academia de Bellas Artes de San Fernando, ya fuera como memorias de aprendizaje o como excusas para algún concurso interno de la institución, sea prácticamente inexistente la copia de láminas del Studio, aun sabiendo que la propia biblioteca de la Academia y muchos de sus profesores lo poseyeron.

Sea como fuere, entre los dibujos conservados en la Biblioteca Nacional, solo algunos, que ya tuve oportunidad de publicar recientemente, muestran una relación directa o indirecta con el Studio y, en algunos casos se trata, con toda probabilidad, de características representaciones de edificios, proyectos y fragmentos de obras romanas realizadas con procedimientos muy semejantes a los usados por Specchi y otros arquitectos colaboradores en el proyecto de Domenico de Rossi, también habituales en los concursos de la Accademia di San Luca. Así, un dibujo [21] con la Escalera del Palacio Barberini (ca. 1735-1745) (BNE/ Dib./14/46/50) ${ }^{107}$, es copia, sin duda, de la Scala a Lumaca del Palzzo Barberini reproducida en la Lámina 42 del primer volumen del Studio. Sin embargo, otros dos, con características gráficas muy próximas tanto a los dibujos preparatorios conocidos, como a las estampas publicadas, pudieran ser contemporáneos del

107 Sobre los tres dibujos de la Biblioteca Nacional aquí mencionados he tratado en las fichas correspondientes del catálogo Isabel García Toraño (a cura di), Dibujos de Arquitectura y Ornamentación de la Biblioteca Nacional..., pp. 296-297 y 301-302. 


\section{O: artículos}

Delfín Rodríguez Ruiz

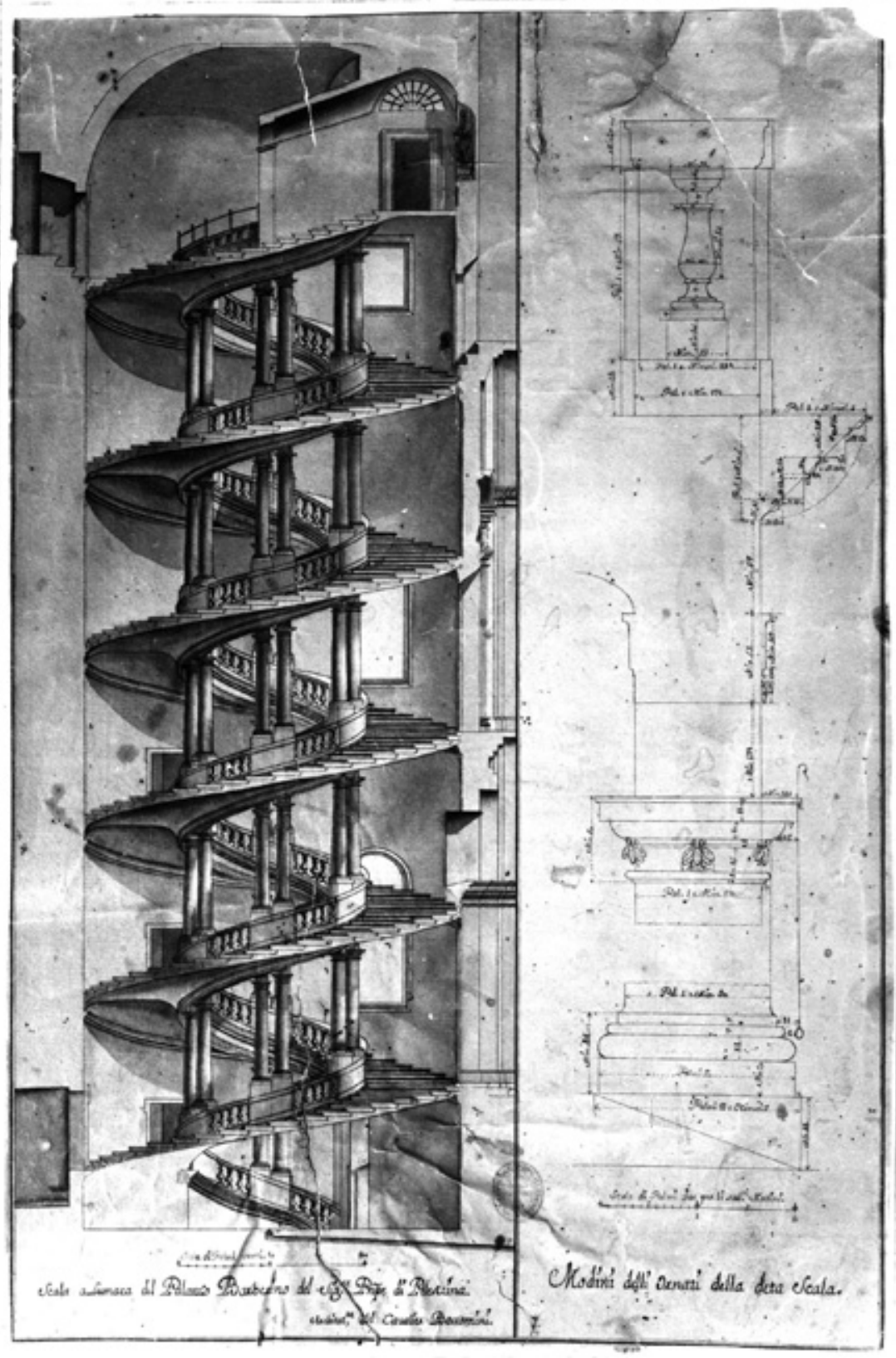

21. Anónimo italiano, Escalera del Palacio Barberini. Dibujo a pluma, tinta y aguadas grises, ca. 1735-1745 (Madrid, Biblioteca Nacional). Es copia de Domenico de Rossi, Studio d'Architettura Civile, I (1702), Lámina, 42, que representa la Scala a Lumaca del Palazzo Barberini 
22. Anónimo italiano, Puerta de la Basílica de San Giovanni Laterano che conduce nel Palazzo Papale Lateranese.

Dibujo a pluma, tinta y aguadas grises y marrones, ca. 1700. (Madrid, Biblioteca Nacional)

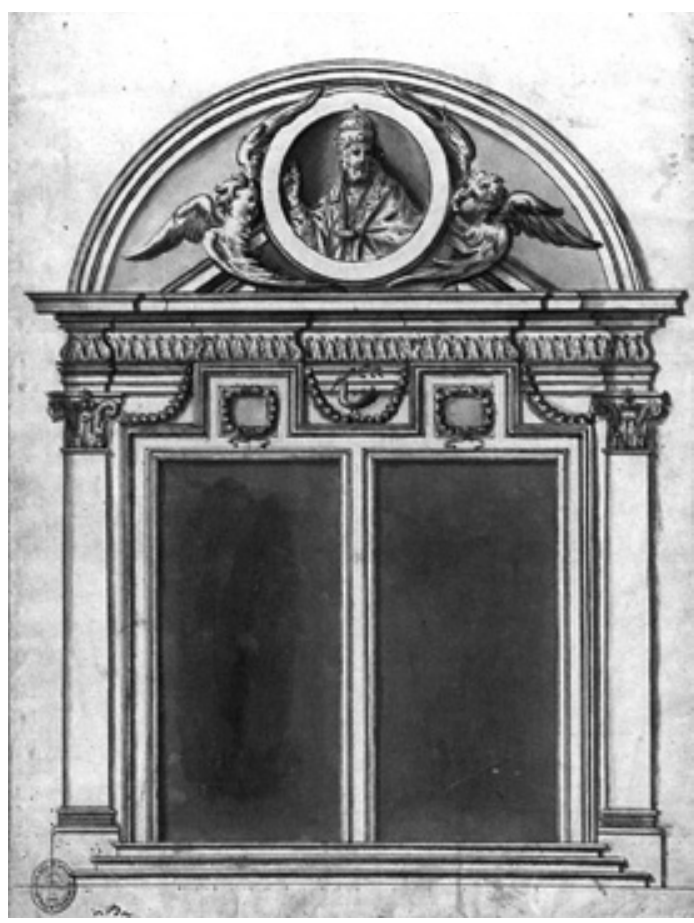

proyecto editorial de Rossi, entre 1700 y 1721 . El primero de ellos representa la Fachada de ingreso a la Cappella Sforza in Santa Maria Maggiore (ca. 1720) (BNE/Dib/18/1/2291), atribuida a Miguel Ángel y destruida, en 1748, durante las reformas de la basílica por Ferdinando Fuga (1699-1781). La planta y sección de la mencionada puerta miguelangelesca recuerdan notablemente los dibujos preparatorios para el Studio, aunque lo cierto es que esa estampa no fue publicada.

Más interés, como posible dibujo preparatorio [22] para una estampa en el contexto del Studio tiene el segundo de los dibujos mencionados, con la representación solo del alzado, sin planta, de la Puerta de la Basílica de San Giovanni in Laterano che conduce nel Palazzo Papale Lateranense (ca.1700) (BNE/ Dib/14/46/51), de Francesco Borromini ${ }^{108}$, reproducida en la Lámina 67 del primer volumen del Studio, aunque existen diferencias muy notables que obligarían a retrasar la fecha del dibujo a años posteriores a la edición de 1702, posiblemente

108 Sobre el significado de estos peculiares "portali binati» de Borromini, véase, entre otros, Marcello Fagiolo, "Borromini in Laterano. "Il Nuovo Tempio" per il Concilio universale", L'Arte, n. ${ }^{\circ} 13,1971, \mathrm{pp}$. 5-44. 
vinculado a un ejercicio académico, aunque de enorme calidad. Tal vez algunos otros dibujos de edificios y altares romanos pudieran ponerse relación con el Studio, pero más como ejemplos representativos de convicciones comunes, compartidas entre el proyecto editorial y la formación y cultura de los arquitectos que trabajaron en Roma durante el primer tercio del siglo XVIII, especialmente en el ámbito de la Accademia di San Luca. 